NBER WORKING PAPER SERIES

\title{
AN EMPIRICAL ANALYSIS OF THE ECONOMIC IMPACT \\ OF FEDERAL TERRORISM REINSURANCE
}

Jeffrey R. Brown

J. David Cummins

Christopher M. Lewis

Ran Wei

Working Paper 10388

http://www.nber.org/papers/w10388

\author{
NATIONAL BUREAU OF ECONOMIC RESEARCH \\ 1050 Massachusetts Avenue \\ Cambridge, MA 02138 \\ March 2004
}

\begin{abstract}
The views expressed herein are those of the author and not necessarily those of the National Bureau of Economic Research.

(C2004 by Jeffrey R. Brown, J. David Cummins, Christopher M. Lewis, and Ran Wei. All rights reserved. Short sections of text, not to exceed two paragraphs, may be quoted without explicit permission provided that full credit, including (C) notice, is given to the source.
\end{abstract}


An Empirical Analysis of the Economic Impact of Federal Terrorism Reinsurance

Jeffrey R. Brown, J. David Cummins, Christopher M. Lewis, and Ran Wei

NBER Working Paper No. 10388

March 2004

JEL No. G14, G22, G28

\section{ABSTRACT}

This paper examines the role of the federal government in the market for terrorism reinsurance. We investigate the stock price response of affected industries to a sequence of thirteen events culminating in the enactment of the Terrorism Risk Insurance Act (TRIA) of 2002. In the industries most likely to be affected by TRIA - banking, construction, insurance, real estate investment trusts, transportation, and public utilities - the stock price effect was primarily negative. The Act was at best value-neutral for property-casualty insurers because it eliminated the option not to offer terrorism insurance. The negative response of the other industries may be attributable to the Act's impeding more efficient private market solutions, failing to address nuclear, chemical, and biological hazards, and reducing market expectations of federal assistance following future terrorist attacks.

Jeffrey R. Brown

Department of Finance

University of Illinois at Urbana-Champaign

340 Wohlers Hall, MC-706

1206 South Sixth Street

Champaign, IL 61820-9080

and NBER

brownjr@uiuc.edu

J. David Cummins

University of Pennsylvania

The Wharton School

3641 Locust Walk

Philadelphia, PA 19104-6365

cummins@wharton.upenn.edu
Christopher M. Lewis

The Hartford

55 Farmington Avenue, Suite 700

Hartford, CT 06105

chris.lewis@thehartford.com

Ran Wei

University of Pennsylvania

The Wharton School

3641 Locust Walk

Philadelphia, PA 19104-6365

rwei@wharton.upenn.edu 


\section{Introduction}

What are the effects of insurance, or the lack thereof, on the economy? This question was posed with particular urgency with the virtual collapse of the market for terrorism insurance and reinsurance following the September 11, 2001 terrorist attacks. Congress responded to predictions of dire economic consequences by passing the Terrorism Risk Insurance Act (TRIA) in November 2002. The objective of the Act is to restore the market for terrorism insurance in the U.S. by providing a federal reinsurance backstop for U.S. commercial property-liability insurers. On signing the bill, President Bush remarked that it would "strengthen America's economy, build confidence with America's investors, and create jobs for America's workers." He attributed billions of dollars of cancelled or postponed construction projects, downgraded financial ratings for mortgage-backed securities, and other severe economic consequences to the inability of businesses to secure insurance against terrorism risk. ${ }^{1}$

The objective of this paper is to provide empirical evidence on whether TRIA has had the intended economic effects by studying the stock price reaction of firms in the industries most affected by the Act - banking, construction, insurance, real estate investment trusts (REITs), transportation, and public utilities. ${ }^{2}$ We examine the stock price response of affected industries to a sequence of thirteen key legislative events beginning with the initial proposals for a federal reinsurance role in October 2001 and culminating in the signing of the Act into law on November 26, 2002.

Based on the characteristics of TRIA and theoretical considerations, we formulate hypotheses about the anticipated impact of the Act on affected industries. We argue that TRIA was at best valueneutral for the property-casualty industry, the industry most directly impacted by the Act. In the months following September 11, 2001, insurers eliminated terrorism coverage from most large commercial insurance policies. By nullifying these exclusions and requiring insurers to offer terrorism coverage, TRIA increased the potential exposure of the industry to terrorism losses. Moreover, the Act had little

\footnotetext{
${ }^{1}$ George W. Bush, "Remarks on signing the Terrorism Risk Insurance Act of 2002," Weekly Compilation of Presidential Documents, Proquest Information and Learning, December 2, 2002.

${ }^{2}$ We recognize that the effect of an event on stock prices does not necessarily measure the effect of an event on economic welfare. For example, government action to prevent collusive behavior could have an adverse stock price effect on the colluding firms but have a beneficial effect on economic welfare more generally. However, because TRIA was designed to benefit the economy by making terrorism insurance available to the affected industries, measuring the stock price impact of the Act provides a meaningful indication of its success.
} 
impact on the international reinsurance market, which is dominated by foreign reinsurers. By providing "free" government reinsurance, the Act may have actually delayed or prevented the reemergence of private sector reinsurance for terrorism losses. U.S. insurers are now required to cover terrorism but are unable in most cases to purchase adequate private reinsurance to cover the deductible and co-payment loss exposure created by TRIA. Although the Act created a layer of federal terrorism reinsurance, to the extent that insurance markets are competitive it is unlikely that insurers will be able to earn economic rents by pricing the federal coverage layer into insurance policies.

The predicted effects of TRIA on the other affected industries are also ambiguous. To the extent that the Act resulted in an increase in the supply of available insurance coverage, affected industries such as banking and construction could be expected to benefit from passage of the Act. Although TRIA requires insurers to offer terrorism insurance to their commercial clients, there is no requirement that businesses purchase, nor are prices regulated by the legislation. If, as appears to be the case, many businesses decide to not to insure even with TRIA in place, then the potential benefits of the Act will be blunted. To the extent that the existence of TRIA has impeded the emergence of more efficient private market mechanisms for financing terrorism losses, the net impact of the Act may well have been negative. Moreover, the Act does not provide coverage for nuclear, chemical, or biological hazards, which may be the most serious threats from future terrorism. Finally, the Act may have lowered the market's expectations regarding federal assistance to industries affected by future terrorist attacks by substituting a carefully circumscribed reinsurance program for more open-ended federal disaster assistance, a type of Samaritan's dilemma effect.

To investigate these effects empirically, we analyze the largest possible sample of firms in the affected industries that are traded on the New York Stock Exchange, the American Exchange, and Nasdaq for which sufficient data were available to conduct the analysis. Because the events analyzed in the study affect all sample firms simultaneously, it would not be appropriate to utilize the standard event study methodology, which assumes that random errors are independent and homoskedastic across observations. Accordingly, we adopt the multivariate regression model (MVRM) approach, which allows for cross- 
sectional heteroskedasticity and potential dependence among residuals. The regression models have individual firm stock returns as dependent variables and market returns and event dummy variables as regressors. Separate regression models are estimated for each industry and each event. Because legislative events are not always as sharply defined as most other news events affecting stock prices, we analyze several event windows surrounding each event. The impact of each event is measured as the cumulative abnormal return on each stock over the event windows, and the average cumulative abnormal returns are tested for statistical significance to measure the effect of the events on each industry.

To provide an economic context for the event study results, we also present data on some additional economic time series surrounding the World Trade Center and TRIA events. These data are of two primary types - economic time series showing aggregate trends in relevant variables such as construction expenditures and construction lending, and data on developments in property-casualty insurance markets. By analyzing the stock price effect of TRIA and modeling the relevant economic time series, we attempt to provide a comprehensive evaluation of the TRIA's economic impact.

By way of preview, we find that the stock price effect of TRIA on affected industries was primarily negative. For example, for the two final events - Senate passage of the Act (November 20, 2002) and the signing of the bill into law (November 26, 2002) - the stock price effect was significantly negative in most event windows for insurance companies, REITs, transportation firms, and banks. There was a significant positive stock price effect for utilities in the days preceding passage of the Act, but the utilities industry responded negatively to the signing of the bill into law. There were no significant effects for the construction industry for the two ultimate events. These findings cast doubt on the efficacy of TRIA in improving the economic environment of the affected industries.

The remainder of the paper is organized as follows. In section 2, we provide a conceptual framework for the federal role in the market for terrorism insurance by discussing the market failure that led to the government response, theories of government intervention, and policy options. Section 3 describes the events leading up to the passage of TRIA and outlines the provisions of TRIA. Section 4 discusses the hypotheses, study design, methodology, and results; and section 5 concludes. 


\section{A Framework for Government Intervention in the Terrorism Insurance Market}

In the months following the terrorist attacks on September $11^{\text {th }}, 2001$, members of the propertycasualty insurance industry and other sectors began calling for the federal government to assume a role in providing financial protection against future terrorism losses. In many ways, these calls for federal intervention in the insurance markets were reminiscent of industry reactions following Hurricane Andrew and the Northridge earthquake. However, because the merits of government intervention in the market for terrorism insurance are still being debated, it is useful to examine the principal theories that have been advanced concerning the appropriate government role in responding to private market failures generally. We can then examine the nature of possible "failures" in the market for terrorism insurance in more detail to provide the important context for understanding the development and potential effects of TRIA.

There are three primary theories of public policy concerning the appropriate role of government in addressing market failures in the insurance industry: laissez faire, public interest theory, and marketenhancing policies. The fundamental premises - and policy prescriptions - associated with each of these policy camps are quite different. Laissez-faire public policy maintains that any market-based equilibrium, however imperfect, still provides a more efficient allocation of resources within the economy than an equilibrium involving government intervention. In the absence of distortion-inducing government intervention, the outcome of decentralized private sector activity will remain more efficient, even in a second-best sense, than a market equilibrium with government intervention. From this perspective, government intervention in markets results primarily from rent-seeking behavior of special interest groups seeking to bolster their allocation of societal wealth (e.g., Stigler, 1971; Peltzman, 1989). From this perspective, industry calls for government protection against terrorism risk may be viewed as opportunistic attempts to secure an ex ante wealth transfer from taxpayers.

The public interest theory of regulation contests this view (Musgrave and Musgrave, 1984). Public interest theory suggests that the existence of market failures (e.g., moral hazard, economies of scale, externalities) can lead to a sub-optimal allocation of resources and that government intervention targeted at addressing these market failures can improve welfare. Whereas laissez faire policy suggests 
that private sector coordination is optimal, public interest theory suggests that, in specific instances, the government can improve upon the market equilibrium by substituting for private sector coordination. The challenge for public interest theory is to narrowly define the market failure and devise a minimalist policy to correct this failure without creating additional distortions in the allocation of market resources.

Proponents of public interest theory, therefore, may maintain that the information asymmetries and bankruptcy costs associated with the market for terrorism insurance may necessitate the role of the government in "completing" the market for terrorism insurance.

The third view of public policy intervention, the market-enhancing view, takes a middle position (Lewis and Murdock, 1996, 1999). The market-enhancing view recognizes that market failures can create sub-optimal allocations of wealth and that private-sector coordination is not always effective. This view holds that public policy should facilitate the development of the private market, such as by improving information flows, but should not create new federal institutions to substitute for private solutions. As an example, the market-enhancing view would suggest that the federal government's flood mapping program may have provided valuable information to the market on flood zone risks, but that the provision of flood insurance should be left to private institutions. At the same time, market-enhancing policy recognizes that federal regulation can help facilitate the creation or enhancement of private institutions for solving market failures such as the federal role in facilitating mortgage securitization markets in the U.S. ${ }^{3}$

In evaluating the role of the federal government in the terrorism insurance market, it is useful to compare the terrorism insurance debate with the calls for government intervention in the market for natural disaster risk - another low frequency and high severity catastrophe risk. Beginning with Hurricane Andrew in 1992, market expectations with regard to the frequency and severity of catastrophic property events increased dramatically. ${ }^{4}$ Such low frequency, high severity events are particularly challenging financing problems for private insurance markets. Insurance works best for smaller, more frequent events, where it is possible to gather sufficient statistical data to support actuarial pricing

\footnotetext{
${ }^{3}$ The flip side of this argument is that a government-sponsored enterprises' special privileges may remain fully in place years later, even if the market failures no longer exist.

${ }^{4}$ Andrew was the largest disaster prior to the World Trade Center attacks, with insured losses of about $\$ 20$ billion. The Northridge earthquake in 1994 caused an additional \$17 billion in insured losses, further increasing expectations regarding potential catastrophic claims.
} 
estimates and provide for risk diversification. Projected natural catastrophes, such as a $\$ 100$ billion California earthquake or Florida hurricane, also are large relative to the resources of the insurance industry. Holding additional equity capital in the industry to shield against highly infrequent events would be costly, due to regulatory, tax, and accounting constraints as well as transactions and agency costs (Jaffee and Russell, 1997). Raising capital to pay losses following a large loss event also is difficult because informational asymmetries between capital markets and insurers regarding loss exposure and reserve adequacy would raise the cost of capital to potentially prohibitive levels. Private insurance markets tend to be much more efficient at cross-sectional rather than cross-time diversification.

Unlike the private insurance industry, the federal government may be better positioned to accomplish cross-time diversification because it can raise money following a disaster by borrowing at the risk-free rate of interest and then repay the loans out of tax revenues. ${ }^{5}$ The government's ability to timediversify led to a Clinton administration proposal for government intervention in the market for catastrophic property insurance during the 1990s (Lewis and Murdock, 1996, 1999), whereby the federal government would hold periodic auctions of catastrophic excess of loss (XOL) reinsurance contracts to insurers and reinsurers. The auctions would be conducted subject to a reservation price sufficient to support the expected loss and expense costs under the contracts as well as a risk premium to encourage private market "crowding-out" of the federal reinsurance. If a catastrophe were to occur that triggered payment under the contracts, the federal government would finance the loss payments by issuing bonds. Although the proposal was never adopted, it could provide a model for a different type of federal involvement in the terrorism insurance market consistent with the market enhancing view of regulation.

The market response to the increasing frequency and severity of catastrophe insurance losses in the 1990s has potentially quite significant implications for the terrorism insurance issue. In spite of the lack of federal government intervention in the market for natural catastrophe insurance, the private market for natural catastrophe insurance did not collapse. Although insurance and reinsurance prices rose

\footnotetext{
${ }^{5}$ The assertion that the government has superior ability to time diversify may be challenged on the grounds that it places risks on taxpayers regardless of their willingness to bear them. Further discussion of the consideration of the costs of compensating taxpayers for the burden of supplying capital can be found in Braun, et al, 1998.
} 
following Hurricane Andrew and the Northridge earthquake, significant amounts of new equity capital flowed into the industry and reinsurance prices eventually declined (Guy Carpenter, 2003). For the most part, insurance continued to be available in disaster prone areas such as Florida, and private insurers eventually reentered the market for California earthquake insurance. ${ }^{6}$ There is evidence of continuing market anomalies, however, such as the skewness of reinsurance towards the coverage of relatively small catastrophes and the apparent continuing thinness of reinsurance coverage for mega-catastrophes (Froot, 2001). Nevertheless, it is clear that private markets for natural catastrophe insurance have continued to function with reasonable efficiency in the absence of federal support.

The private market's success in offering insurance and reinsurance against natural catastrophes raises the question as to whether the terrorism insurance market would have rebounded in the absence of TRIA and perhaps might have provided a more efficient solution to the market collapse that followed the World Trade Center attacks. Another way of asking this question is to inquire as to whether terrorism risk is different in some fundamental way from the risk of natural catastrophes. Many of the same elements that make terrorism insurance a difficult problem for private insurance markets are also present in the case of natural catastrophes, namely, the low frequency, high severity nature of the events and their magnitude relative to the resources of the insurance industry. Like terrorism, estimating the frequency and severity of the potential losses for natural disasters initially proved to be a difficult problem for private insurers. However, the market responded in the form of catastrophe modeling firms such as Applied Insurance Research (AIR) and Risk Management Solutions (RMS), which have developed sophisticated models of hurricane and earthquake risks. Such modeling might also be feasible for terrorism risk, and indeed the modeling firms have already begun studying the problem (Woo, 2003).

Among the potentially important differences between terrorism risk and other types of natural and man-made catastrophes are the following: (1) the potential magnitude of the losses may be significantly larger, (2) the frequency and severity of loss may be more difficult to estimate, and (3) the expected loss

\footnotetext{
${ }^{6}$ State government solutions to catastrophe insurance availability problems have tended to involve the creation of pools that are government mandated but privately financed, usually through the insurance industry. E.g., Hawaii and Florida both established state pools to insure hurricane losses following Hurricanes Andrew and Iniki in 1992. In 1996, the California legislature created the California Earthquake Authority, which is a privately financed but publicly managed organization that provides earthquake insurance to California homeowners.
} 
costs and the information needed to estimate costs interacts with government homeland security and defense policies. Regarding magnitude, although a major California or Tokyo earthquake or a major Florida hurricane could cause significant damage, e.g., \$100 billion or more, the potential losses from terrorist attacks are arguably far larger. For example, the detonation of a nuclear device in a major urban center such as New York could cause significantly higher losses, possibly running into trillions of dollars.

Although earthquakes and the storm tracks followed a given season's hurricanes are nearly impossible to predict in advance, science has made considerable progress in modeling these events. Likewise, there is sufficient data on oil spills and other non-terrorist man-made disasters to permit insurers to estimate loss costs. Terrorist attacks, on the other hand, are based on deliberate human acts, undertaken with the intent of avoiding detection and causing as much damage as possible. Such actions are inherently more difficult to predict and are outside the realm of traditional actuarial and scientific modeling. Moreover, the past statistical loss experience with major attacks is insufficient to permit the use of conventional empirical techniques. Although multi-disciplinary modeling approaches can be developed that will aid in estimating terrorism losses, such modeling clearly poses unique challenges.

The third major difference between terrorism and other types of catastrophes is that the frequency and severity of terrorist attacks are also affected by U.S. governmental policy. U.S. foreign policy directly impacts the motivation and likelihood of terrorist attacks from different militant factions. U.S. domestic policy and the success of governmental homeland security programs also affects the mitigation of terrorist attacks - both in preventing such attacks and mitigating the magnitude of any attack that does occur. Moreover, much of the information required to predict terrorist events is likely to remain highly classified and unavailable to those outside of agencies such as the FBI and CIA. In fact, one of the arguments proffered in support of a federal role in the provision of terrorism insurance was that terrorism events represent a negative externality of the national security policies of the sovereign government.

Thus, there are a number of reasons to believe that the private market will have difficulty in solving the terrorism risk insurance problem, at least for the largest and least frequent events, arguing for some type of federal role. Nevertheless, there is evidence that some terrorism insurance was becoming 
available even prior to the passage of TRIA, indicating that a private market solution may have been emerging. Moreover, even if terrorism represents a negative externality of government foreign policy, the most efficient mechanism for financing terrorism losses may still reside within the private sector, especially given the prominent role of property-specific loss mitigation in managing terrorism exposure. Thus, the private market still might be able to provide a more efficient solution for terrorist events, especially in the relatively low coverage layers. By examining the market reaction to the development of federal legislation for terrorism insurance within key industries, we can obtain a glimpse at how the market perceives the role of the government in the provision of terrorism insurance.

As the empirical results will show, the government's reaction to the calls for federal assistance in the terrorism insurance market sends a mixed message with regard to the underlying theory of intervention. On the one hand, an insurance industry proposal for a more or less permanent federal reinsurance program was quickly dismissed by policymakers, and TRIA as enacted contains a stringent sunset provision. This response could be interpreted as an indication that policymakers viewed industry demands for government intervention as "opportunistic rent-seeking” by industries looking for societal cross-subsidization in the management of terrorism risk. On the other hand, the program design adopted under TRIA inserted the government somewhat more intrusively into the market for terrorism reinsurance than might have been considered desirable under a purely market-enhancing rationale for intervention. This relatively aggressive government intervention may have led to expectations that inefficiencies and other downside risks would adversely impact the industries most dependent on terrorism insurance.

\section{The Terrorism Risk Insurance Act of 2002}

\subsection{The Initial Push for Federal Intervention}

Despite insured losses that were estimated at the time to be between $\$ 30$ billion and $\$ 70$ billion, ${ }^{7}$ leaders in the U.S. insurance industry announced in the weeks immediately following $9 / 11 / 2001$ that they would not invoke the "acts of war" exclusions in their policies that might have allowed them to avoid

\footnotetext{
${ }^{7}$ Congressional Budget Office "Federal Reinsurance for Terrorism Risks,” October 2001, page 3.
} 
paying claims stemming from terrorist losses. ${ }^{8}$ However, the industry also made it clear that it was not in a position to continue to insure additional large terrorism losses going forward, and that some form of federal assistance was needed. Maurice "Hank" Greenberg, CEO of the American International Group (AIG), stated "The industry is going to pay its loss in the World Trade Center events. What we're saying is that if terrorist events continue, this is an industry with finite capital."

At a meeting at the White House on September 21, 2001, several insurance industry executives floated the idea of setting up a national terrorism insurance pool similar to the "Pool Re" program set up by the U.K. in 1993 in response to IRA bombings (Barnes, 2002). The U.K. program established a mutual terrorism reinsurer, Pool Re, funded by the insurers themselves, but with the government agreeing to cover any losses that exceed the reserve. Arrangements between Pool Re and the U.K. government are designed such that the net cost to the taxpayers is zero over a period of years. Like the U.K. plan, the U.S. proposal would have established a terrorism insurer, the Homeland Security Mutual Reinsurance Company, with federal reinsurance backstop for terrorism losses. Unlike the U.K. program, however, the U.S. proposal made the government the "insurer of last resort," i.e., insurers would not have been required to reimburse the federal treasury for reinsurance payments received under the program (Reinsurance Association of America, 2002).

For a number of reasons, the insurance industry proposal did not gain much traction with the Administration or Congress. Concerns were raised that the mechanism for funding the pool through insurance company contributions was inadequate, and that the government would effectively have to step in at a very low level of any future loss. In addition, many officials were concerned that the insurance pool would turn into a permanent fixture in the insurance industry, leading to a permanent intrusion of the federal government into a traditionally state-regulated industry. Also, concerns were raised about the potential for market power that could develop with only a single, industry-controlled pool. As a result of these and other concerns, it became clear that the insurance industry's reinsurance pool proposal was not

\footnotetext{
${ }^{8}$ The Associated Press State \& Local Wire, “Insurance industry leaders reassure White House," September 23, 2001.

${ }^{9}$ Hamburger, Tom and Christopher Oster, "Insurance Industry Backs U.S. Terrorism Fund,” Wall Street Journal, October 9, 2001, p. A.3.
} 
going to proceed successfully to legislation. However, the industry's efforts did move the debate about possible federal intervention onto center stage. By mid-October, the Bush Administration announced that it was prepared to support a proposal for federal intervention in the market for terrorism insurance.

\subsection{The Bush Administration Proposal}

The White House proposal, unveiled on October 15, 2001, called for the federal government to assume responsibility for 80 percent of the first $\$ 20$ billion of insured losses arising from a future terrorist attack, and 90 percent of insured losses in excess of $\$ 20$ billion. This coverage was to have been provided for the rest of 2001 and all of calendar year 2002. For 2003 and 2004, the government's share of losses would decline, both through the use of industry deductibles and through a declining marginal contribution, in an attempt to gradually return responsibility for terrorism coverage to the private sector.

The Administration's proposal was clearly designed to be temporary, with a declining federal role that explicitly sunset after three years. This approach was consistent with the belief that the primary rationale for federal intervention in this market was to provide a temporary transition period during which the private market could rebuild capacity and learn how to model and price insurance (Brown, Kroszner, and Jenn, 2002). The program also capped the combined liability of insurers and the federal government at $\$ 100$ billion. The absolute cap on insurer losses was designed to eliminate the extreme right tail of the loss distribution for insurers, thus reducing exposure and mis-pricing risk, and also was intended to provide Congress with flexibility to respond in the event of a truly catastrophic terrorist strike.

Among economists, one of the most controversial features of the Administration plan was that the federal insurance was being provided for "free" to the industry (although not to the federal treasury). Two arguments were put forth to justify this. The first was simply that setting up a premium structure would lead to the creation of a potentially inefficient and otherwise unnecessary bureaucracy, perhaps making it more difficult for the program to sunset down the road. The second was that the government was not in a position to determine an appropriate price for the insurance, so a price of zero was an implicit fallback. Naturally, there are problems arising from the provision of federal insurance at no cost on the margin. Perhaps the most important is that profit maximizing firms can be expected to optimally divide 
their resources on the margin between insuring losses and investing in risk mitigation. A zero price artificially lowers the cost of insurance, potentially leading to sub-optimal investment in risk mitigation activities. In addition, a zero price provides a severe and probably insurmountable impediment to the reemergence of private terrorism reinsurance.

The Administration plan also contained new limitations on civil actions arising from terrorist activities, i.e., mass tort liability reform. These limitations, which included, for example, the assignment of jurisdiction to a federal court, limits on non-economic damages, and a prohibition on punitive damages, set the stage for rancorous debate with Congress in the months that followed.

\subsection{House and Senate Proposals}

The White House proposal was a clear signal that the Administration was prepared to intervene in the market for terrorism risk insurance. Among the critics of the approach were Republican members of the House, who believed that the Administration proposal would place too great a potential fiscal burden on the U.S. Treasury. Thus, in November 2001, the House introduced and quickly passed a complex piece of legislation to provide for a federal reinsurance program. The proposal differed from the Administration proposal in several ways. First, the House proposal would have sunset federal involvement at the end of December 2002, providing only one year of federal intervention. Second, the House bill included a mechanism whereby Treasury would recoup federal payments ex post by levying premium surcharges on the industry. In other words, the Treasury would step in to help pay for losses arising from a terrorist loss, but planned to recoup at least some of this revenue in the years following. Such ex post cost recoupment, however, would not successfully provide the incentives for risk mitigation that ex ante premiums would. Furthermore, in the aftermath of another terrorist event, the premium surcharges would further distort private sector prices. It seems clear that this mechanism was designed solely to limit the contingent liability facing the Treasury, not to address concerns about incentives.

During November and December 2001, a number of alternative plans were also being debated on the Senate side. The Senate plans generally provided for two years of coverage, with an option to extend for a third year. The federal government would begin covering a share of losses only after the industry 
absorbed the first $\$ 10$ billion in losses. Further details on the Administration proposal, the House proposal, and the leading Senate plan can be found in Table 1.

In addition to differences about how to structure and pay for the insurance element of the program, the House and Senate plans differed significantly with regard to the limitations on mass tort liability claims. The House version contained numerous provisions, including caps on non-economic damages and a prohibition on punitive damages, which many Senate Democrats would not support. Largely as a result of this tort dispute, the Senate adjourned in late December 2001 without an agreement.

\subsection{Terrorism Coverage in the Absence of a Federal Program}

As a result of the breakdown of negotiations in the Senate, 2002 began with no legislation in place to provide for a federal role in the market for terrorism insurance. After the September $11^{\text {th }}$ terrorist attacks, reinsurers began writing terrorism exclusions into their policies. A majority of those contracts renewed at the beginning of January $2002,{ }^{10}$ leaving U.S. primary insurers with virtually no opportunity to reinsure their exposure. As a result, the primary insurers' exposure to terrorism risk increased, at least until insurers were able, in turn, to write terrorism exclusions into their own policies. Recognizing that substantial exposure to terrorism risk without adequate opportunities for reinsurance could pose substantial solvency risks, state insurance regulators were rapidly approving terrorism exclusions. By early 2002, insurance regulators in 45 states had approved the use of terrorism exclusions. These exclusions meant that insurers in those states were permitted to exclude from their standard commercial insurance coverage any losses arising due to a terrorist event, meaning that business and property owners would no longer be able to count on an insurance payoff in the event of a loss due to terrorist activity. ${ }^{11}$

Unlike reinsurance contracts, the renewal dates of which are heavily concentrated in January, renewals of primary insurance contracts are spread more uniformly through the year. Thus, the extent of risk shifting from primary insurers and onto business and property owners increased as the year progressed. In February 2002, the GAO gave Congressional testimony providing "examples of large

\footnotetext{
${ }^{10}$ GAO-02-472T, “Terrorism Insurance: Rising Uninsured Exposure to Attacks Heightens Potential Economic Vulnerabilities."

${ }^{11}$ An exception to the general exclusion of terrorism from commercial insurance policies following $9 / 11$ is coverage for workers' compensation insurance. Workers' compensation is mandated by state law to cover work injuries from all causes, and the states did not revise the workers' compensation laws to allow terrorism exclusions.
} 
projects canceling or experiencing delays have surfaced, with the lack of terrorism coverage being cited as the principal contributing factor."12 According to a survey by Council of Insurance Agents and Brokers, in the first quarter of 2002, the market for property-casualty insurance experienced "sharply higher premiums, higher deductibles, lower limits and restricted capacity from coast to coast and across the major lines of commercial insurance." ${ }^{13}$ By October, 2002, President Bush claimed that over $\$ 15.5$ billion worth of construction projects were "not going forward because they can't get insurance on their projects, can’t insure the buildings or the project." ${ }^{\text {14 }}$ These anecdotal statistics are quoted here to exemplify the type of information that motivated passage of the Act.

\subsection{The Terrorism Risk Insurance Act of 2002 (TRIA)}

In the summer of 2002, after many months of inaction, the Senate reinitiated its efforts to pass terrorism insurance legislation. The Senate passed a bill in June that differed substantially from the House bill. The months that followed were focused on negotiations between the House and the Senate over how to create a bill that both houses could support. This debate proved rancorous, and once again the debate over tort reform threatened to derail the process. It was not until after the mid-term elections in November 2002 that agreement was finally reached during an all-night marathon negotiation session. The Terrorism Risk Insurance Act of 2002 was signed into law by President Bush on November 26, 2002, more than 14 months after the terrorist attacks that precipitated its creation.

TRIA established the Terrorism Insurance Program within the Department of the Treasury. The program, which expires on December 31,2005, covers commercial property-casualty insurance, and all insurers operating in the U.S. are required to participate. Through the end of 2004, insurers are required to "make available property and casualty insurance coverage for insured losses that does not differ materially from the terms, amounts, and other coverage limitations applicable to losses arising from events other than terrorism." 15 The Secretary of the Treasury has the authority to extend the "make available" provision one additional year, through the end of the three-year program. In short, this

\footnotetext{
${ }^{12}$ GAO testimony page 9

${ }^{13}$ CIAB press release $4 / 16 / 2002$

${ }^{14}$ President Bush remarks October 1, 2002

${ }^{15}$ Page 7 of TRIA legislation
} 
legislation nullified the state terrorism exclusions, and requires that insurers offer terrorism coverage. ${ }^{16}$ The wording of the Act implicitly omits coverage of nuclear, chemical, and biological hazards, which are not covered by commercial property-casualty policies.

For the federal government to provide payment under this Act, the Secretary of the Treasury must certify that a loss was due to an act of terrorism, defined as a violent act or an act that is dangerous to human life, property or infrastructure, and to have "been committed by an individual or individuals acting on behalf of any foreign person or foreign interest, as part of an effort to coerce the civilian population of the United States or to influence the policy ... of the United States Government by coercion."17 Acts of war are excluded, and losses from any terrorist act must exceed $\$ 5$ million before the Act takes effect.

If a loss meets these requirements, the loss is shared by the insurance industry and the federal government under the deductible, copayment, and recoupment provisions of the Act. The coverage structure of the Act is diagrammed in Figure 1. In 2003, for example, each individual insurer has a terrorism insurance deductible of 7 percent of its direct earned premiums from the prior calendar year. ${ }^{18}$ Above this amount, the federal government pays for 90 percent of all insured losses. However, law provides for mandatory recoupment of the federal share of losses up to the level of the "insurance marketplace aggregate retention limit," set at $\$ 10$ billion in the first year of the program. ${ }^{19}$ This recoupment is to occur through "terrorism loss risk-spreading premiums," a premium surcharge on property-casualty insurance policies in force after the event with a maximum surcharge of $3 \%$ of premiums per year. In addition, the Treasury Secretary has the discretion to demand additional recoupment, taking into account the cost to taxpayers, the economic conditions of the commercial marketplace, the affordability of insurance, and "such other factors as the Secretary considers appropriate." In other words, the Treasury Secretary could choose to recoup 100 percent of federal outlays under this program through ex post premium surcharges. As with the earliest proposals, the total,

\footnotetext{
${ }^{16}$ In this paper we use the term "terrorism coverage" as shorthand for a policy that does not contain a specific terrorism exclusion.

${ }_{17}^{17}$ Page 3 of TRIA legislation

${ }^{18}$ This insurer deductible rises to 10 percent in 2004 and 15 percent in 2005.

${ }^{19}$ This "Insurance Market Aggregate Retention" rises to \$12.5 billion in 2004, and \$15 billion if extended to 2005.
} 
combined liability of both the government and private insurers is capped at $\$ 100$ billion. $^{20}$

\section{Financial Market Response to TRIA 2002}

We analyze the effects of TRIA by studying the stock prices of firms in the industries most likely to be affected by the Act. The use of market value data is more powerful than other approaches in studying the effects of events such as the passage of new legislation because market prices immediately reflect the market's assessment of new information on the affected firms and industries (Schwert, 1981). Because the value of any asset is determined by the expected value of its future cash flows, developing hypotheses about TRIA requires an analysis of the potential effects of the Act on the cash flows of firms participating in the market for terrorism insurance. The objective of this section is to formulate hypotheses about the likely effects of TRIA. We begin with a general discussion of the industries most likely to be affected by the Act and then turn to a more conceptual discussion of the potential effects of the Act on securities market expectations.

\subsection{Potential Effects of TRIA}

\subsubsection{Industries Most Likely To Be Affected}

The industry most likely to be affected by the Act is the property-casualty $(\mathrm{P} \& \mathrm{C})$ insurance industry. P\&C insurers were the primary advocates of federal intervention in months following 9/11/01. Thus, it might seem natural to presume that industry leaders believed that federal legislation would be good for the industry, suggesting that favorable news about that legislation would positively impact P\&C insurer stocks. By restoring the market for terrorism insurance and reinsurance, TRIA provided an opportunity for insurers to increase their revenues. Furthermore, by capping industry losses, the Act limits insurer losses from terrorism. On the other hand, the reinsurance coverage under TRIA is structured very differently from the industry's initial "Homeland Mutual" proposal, and it is difficult to construe the deductible, co-payment, and recoupment provisions of the Act as benefiting the industry. Moreover, TRIA had little impact on the international reinsurance market, which is dominated by foreign

\footnotetext{
${ }^{20}$ The final legislation included a limited amount of "litigation management" features, including the exclusion of punitive damages from coverage under the program, and federal, rather than state, jurisdiction in cases arising from the terrorist act.
} 
insurers. Thus, U.S. insurers are required to offer terrorism coverage, but they are unable in most cases to purchase private reinsurance to cover their deductible and co-payment losses.

Even if TRIA were found to have a non-positive effect on P\&C insurers, however, this would not mean that the market viewed TRIA negatively overall. After all, supporters of TRIA were always careful to argue that this legislation was not simply a "bailout" of the insurance industry, and most of the debate focused on the broader economic implications of legislation for other industries. Indeed, on signing the bill into law, President Bush cited billions of dollars of cancelled or postponed construction projects, downgraded financial ratings for mortgage-backed securities, and other adverse economic consequences. ${ }^{21}$ The idea that this legislation was needed to support numerous industries was summarized by a spokesperson for the Financial Service Roundtable this way: "The issue is about the economy. If you can't get insurance, you can't get loans. If you can't get loans, you can't construct new buildings. If you can't construct buildings, people cannot go to work. It affects everybody."22

The following sectors were often singled out as likely beneficiaries of the legislation:

1. Real Estate: There were two primary concerns raised for property owners. The first was that, in the absence of a functioning insurance market, property owners would be required to bear the risk of terrorism losses themselves. Second, lenders typically require businesses to insure any property that is used to secure a loan. As such, in the absence of insurance, existing commercial properties might be more difficult to sell, thus creating liquidity problems.

2. Construction: Because lenders typically require insurance, concerns were voiced that new construction projects might not be able to secure financing, leading to delays or cancellations of projects.

3. Banking: Because most banks require proof of insurance on properties as an on-going covenant on a loan, the absence of insurance against terrorism risk would cause "technical defaults" on loans. As a result, the unavailability of terrorism insurance would force banks to either waive these technical defaults and bear some of the terrorism risk themselves, or start accelerating payments and calling in loans.

4. Transportation: Especially due to the nature of the terrorist attacks of 9/11/01, there was great apprehension that, in the absence of insurance, railroads, trucking companies, and ships would be unable to transport many types of cargo or face limitations on their destinations.

5. Utilities: In the aftermath of $9 / 11 / 01$, serious concerns were raised about the vulnerability of power plants, particularly nuclear plants. The primary concern was that, absent insurance

\footnotetext{
${ }^{21}$ President George W. Bush, "Remarks on signing the Terrorism Risk Insurance Act of 2002," Weekly Compilation of Presidential Documents, Proquest Information and Learning, December 2, 2002.

${ }^{22}$ Remarks by Lisa McGreevy of Financial Services Roundtable, November 7, 2001
} 
coverage, utilities would have to bear this risk, pass it along to consumers through higher prices, or scale back operations at vulnerable plants.

The clear message of the political rhetoric supporting a federal insurance program was that these affected industries would be the primary beneficiaries. Thus, if TRIA were to provide a net benefit to the economy, it would be reasonable to predict that positive news about likelihood of enacting a federal program result in positive equity price movements for companies in the affected industries. Likewise, if the program is viewed by securities markets as adversely affecting the economy, the effects would be expected to be most pronounced in $\mathrm{P} \& \mathrm{C}$ insurance and the other industries identified above.

Two other potentially interesting industries to consider are life insurance and insurance agents and brokers. The shock to the life insurance industry from September 11 was about $\$ 3$ billion, not nearly as large as that to P\&C insurers. ${ }^{23}$ Because life insurers did not suffer the same capital shock as P\&C insurers, and because life insurers were less active in lobbying for a federal role, they were generally "left out" of the federal terrorism legislative process. In some respects, therefore, they represent an interesting control group for studying the effects of TRIA on insurers. Agents and brokers represent another interesting control group because they are generally compensated as a percentage of premium revenues but typically take no underwriting risk. Thus, any legislation leading to an increase in insurance premiums would seem to benefit agents and brokers, without subjecting them to significant risk of incurring losses under the Act's deductible and co-payment provisions.

\subsubsection{Hypothesized Effects of TRIA}

In general, TRIA could be expected to have both direct and indirect effects on the cash flows of P\&C insurers. The direct effects would include the impact on premium and loss cash flows for losses arising from terrorist events. To the extent that the Act resulted in additional insurance coverage being issued, the P\&C insurance industry would receive additional revenues and would be liable for losses covered by the insurance. Part of these losses would be borne by the industry in the form of deductibles and copayments, and part would be borne by the federal government to the extent that the Treasury's

\footnotetext{
${ }^{23}$ Insurance Information Institute, 2002, “The Long Shadow of September 11 - Impacts \& Implications for Insurers and Reinsurers," PowerPoint presentation, New York.
} 
discretionary recoupment option is not fully exercised following future terrorist attacks. In a competitive market, it would be anticipated that the premiums collected by insurers would be sufficient to cover their expected losses under the program, including a fair profit provision. Losses priced into the policies would include any expected costs arising out of the Treasury's recoupment option as well as potential costs arising from coverage disputes and delays in payment by the Treasury. Because insurance markets are generally competitive, insurers would not be expected to be able to earn rents by pricing the expected value of unrecouped federal reinsurance payments into terrorism insurance policies. Thus, to the extent that markets are rational and competitive, TRIA might be expected to have little or no net effect on the $\mathrm{P} \& \mathrm{C}$ industry, i.e., terrorism insurance could be expected to be priced as a zero net present value project.

However, there are also reasons to believe that TRIA could have a net negative effect on the P\&C insurance industry. The unambiguous and almost immediate insurance market response to the $9 / 11$ terrorist attacks was the disappearance of terrorism insurance and reinsurance coverage. If insurance markets are rational and competitive, this response revealed that insurers did not believe that terrorism insurance could be written at a break even profit rate, i.e., the industry reacted as if writing terrorism insurance would reduce shareholder market value. This response is most likely attributable to the increased parameter uncertainty regarding terrorist events as well as the potential magnitude of such events relative to industry capital. ${ }^{24}$ As noted earlier, state regulators, concerned about insolvency risk, allowed insurers to eliminate terrorism coverage from commercial insurance policies by early 2002. By nullifying these exclusions and requiring insurers to offer terrorism coverage, TRIA effectively reversed the state-endorsed competitive market response to $9 / 11$. In effect, insurers had the option, prior to November 2002, of offering or not offering terrorism coverage; and the Act eliminated the option not to offer. The indirect effects of TRIA on insurers also are likely to be mostly adverse. These effects include anticipated transactions costs generated by government regulatory and reporting requirements under the Act, to the extent that such costs cannot be recovered from policyholders, as well as market inefficiencies

\footnotetext{
${ }^{24}$ Thus, the industry response to the $9 / 11$ terrorist attack parallels developments following the commercial liability insurance crisis of the 1980s as well as natural catastrophes such as Hurricane Andrew and the Northridge earthquake. See Cummins, Harrington, and Klein (1991) and Froot and O’Connell (1999).
} 
arising from governmental intervention in the insurance and reinsurance markets. Thus, at best, TRIA appears to be value-neutral for $\mathrm{P} \& \mathrm{C}$ insurers and a net negative effect would not be surprising.

The possibility also exists that TRIA had more general indirect effects on the economy. Such effects could include a type of "Samaritan's dilemma" problem (e.g., Buchanan, 1975). That is, prior to the Act, there may have been some expectation that the government would intervene to compensate uncovered terrorism losses and/or to shelter firms from insolvency arising from such losses. The assistance to the airline industry following the World Trade Center attacks undoubtedly fueled such expectations, at least for some industries. It is also possible that the markets in general may have been expecting some degree of explicit "socialization" of the losses from nuclear, chemical, or biological attacks. Although the existence and nature of such effects are highly uncertain, it is possible that the government's provision of carefully prescribed terrorism reinsurance protection lowered overall market expectations about future governmental cash flows to industries affected by terrorist events.

Another potentially adverse indirect effect of the legislation is its potential for preventing or delaying the development of efficient private market mechanisms for financing terrorism losses. The private market arguably would provide a much more efficient mechanism for covering terrorism losses than a piece of federal legislation that came into existence through political compromise rather than the operation of the market. Not only does the existence of TRIA potentially discourage market innovation, but its pricing of federal reinsurance coverage at zero virtually guarantees that private reinsurance will not reemerge during the existence of the program. Hence, to the extent that securities markets anticipated the reemergence of efficient private market alternatives, the Act might be expected to have an adverse effect on firms exposed to terrorism losses.

A final comment has to do with the role of terrorism insurance in some of the potentially affected industries. Terrorism can be viewed as a low probability, high severity event. As such, firms facing potential terrorism losses could benefit from a well-functioning terrorism insurance market. Nevertheless, terrorism remains only one of many events, some insurable and some not insurable, that affect the value of the industries analyzed in this paper. To the extent that exposed properties, such as large office 
buildings, are held by well-diversified investors owning securities such as mortgage-backed bonds and shares in REITs, investors benefit because the number of properties likely to be affected by an attack will be small relative to the total number of properties in their portfolios. Thus, holding a diversified portfolio creates "homemade insurance" which may be as effective in some respects as formal coverage purchased in insurance markets. Moreover, to the extent that a major terrorist attack has systematic market effects on portfolio credit quality and asset values more generally, such market-wide effects are not covered by insurance in any event. Therefore, although terrorism clearly has the potential to impose major costs on specific investors and specific businesses operating in affected industries, to some extent diversified investing may provide a more efficient mechanism for financing terrorism losses.

On net, our prediction regarding industries other than $\mathrm{P} \& \mathrm{C}$ insurance is ambiguous. By potentially creating a large transfer payment from taxpayers to affected industries and by restoring, at least to a limited extent, the market for terrorism insurance, the Act could be expected to have a positive market value impact for the affected industries. However, to the extent that the Act led to a net reduction in expected future governmental transfer payments to industries affected by terrorism, impeded the development of more efficient private market solutions, and created transactions costs and other inefficiencies, the net effect of TRIA on industries other than P\&C insurance may be adverse.

\subsection{Event Study Analysis of Key TRIA Legislative Events}

We next investigate how the financial markets perceived federal intervention into the market for terrorism insurance. To do this, we utilize an event study methodology, thus relying on rationality of the market to reflect the value of TRIA in the asset prices of the affected industries.

\subsubsection{Event definitions}

In an ideal event study, the release of information occurs within a very well-defined event window, so that there is little ambiguity about the timing of the information release. In examining the evolution of legislative initiatives, however, the timing of information release can be more problematic and require greater care in defining the event windows being examined. However, there is a long history of research investigating the impact of legislative events on stock prices, ranging from the effect of the 
1986 federal tax reform act (Cutler, 1988), to financial services deregulation (e.g., James, 1983; Cornett and Tehranian, 1990), and legislation directed at regulating the market for corporate takeovers (e.g., Schumann, 1988). ${ }^{25}$ As indicated above, identifying a "clean" event window is more difficult with legislative events, as the information is often muddled, and tends to "trickle out" over time as the legislation goes through multiple iterations, negotiations, and debates. The legislative path to the passage of TRIA was unquestionably a circuitous one. In the last quarter of 2001, competing proposals were unveiled by the White House, the House Financial Services Committee, and various combinations of Senators. Disputes over tort reform "killed" the legislation in late December, but it was then reborn in June 2002. Only after a series of stops and starts did the legislation ultimately pass.

While such a muddled path makes event studies more difficult, we are fortunate that on several key dates, there was a clear release of information that should have led to a definite revision of prior expectations about the probability that TRIA would become law. These particularly "clean" event dates provide the best opportunity to learn about the market's reaction to TRIA, and for these dates, we can confidently use fairly narrow event windows to measure the market effect. We also examine other important event dates in the life of TRIA, for which the exact timing of the information release was somewhat less clear. In these cases, we are careful to examine slightly broader event windows in order to capture any potential "leakage" of information in the days prior to the event.

We have selected 13 key event dates with which to test for market value changes in response to developments in the drafting and passage of TRIA. The first 6 dates are from the fourth quarter of 2001. These dates trace the initial negative reaction to the insurance industry proposal, the unveiling of the White House's proposal, actions leading to passage of H.R. 3210 in the House, and the final collapse of agreement that led the Senate to adjourn in 2001 with no legislation. The second set of 7 events begins in June 2002, when the legislation suddenly came back to life and passed the Senate. These events trace key developments in the House-Senate conference process, ultimately leading to final passage of the revised legislation by both the House and Senate in late November 2002. The last event date is the signing of the

${ }^{25}$ For a review of event studies of the impact of laws and regulations on corporations, see Bhagat and Romano (2002). 
bill into law by President Bush on November 26, 2002. Although it could be argued that the signing of the bill was a virtual certainty following passage by Congress, in view of the President's strong statements supporting terrorism insurance legislation, there was perhaps some residual uncertainty attributable to the tort reform issue and other provisions of the compromise bill. Accordingly, for completeness, we include the signing of the bill as the last event. The 13 events are summarized in Table 2. Column (1) denotes the number that we assign to each event. Column (2) is the calendar date that we denote as date 0 in event time. This corresponds to the calendar date that we have identified as the date of key information release. Below this date, we report the preferred event window that we use in our calculation of cumulative abnormal returns, selected based on our analysis of the legislative process surrounding each announcement date. Column (3) of Table 2 provides a brief description of each event.

\subsubsection{Event Study Methodology}

For each of the 13 event dates detailed in Table 2, we calculate the abnormal returns separately for each of the following industries: P\&C insurers, life insurers, insurance agents and brokers, the overall insurance industry (including P\&C insurers, life insurers, and agents and brokers), banks, REITs, construction, utilities, and transportation. In general, all firms traded on the New York Stock Exchange, the American Stock Exchange, and NASDAQ with adequate data to conduct the analysis were included in each industry sample. More details on sample selection criteria are presented in an Appendix available from the authors.

The standard approach in event-studies is to estimate abnormal returns on potentially affected stocks using the market model, whereby returns on a given stock are regressed on the return on the market portfolio and the abnormal return on day t in the event window for security is calculated as the estimated disturbance term of the market model calculated out-of-sample (see, for example, MacKinlay, 1997). Relying on the standard approach in analyzing the effects of TRIA, however, would not be appropriate because this approach relies on the assumption that the residuals of the market model equation are independent and identically distributed. In this case, both the expected returns and residual variances are likely to differ across firms. Moreover, the residuals will not be independent if the event affects all firms 
at the same time, especially if the firms are in the same or related industries (Schipper and Thompson, 1983; Binder, 1985;). To allow for cross-sectional heteroskedasticity and potential dependence among residuals, we adopt the multivariate regression model (MVRM) approach. The MVRM approach utilizes joint generalized least squares (GLS) to estimate a system of equations to explain the returns of the stocks in a given sample. The system of equations is specified as follows:

$$
\begin{aligned}
& \mathrm{R}_{1 \mathrm{t}}=\alpha_{1}+\beta_{1} \mathrm{R}_{\mathrm{mt}}+\sum_{\mathrm{a}=-\mathrm{w}_{1}}^{\mathrm{w}_{2}} \gamma_{1 \mathrm{a}} \mathrm{D}_{\mathrm{at}}+\varepsilon_{1 \mathrm{t}} \\
& \mathrm{R}_{2 \mathrm{t}}=\alpha_{2}+\beta_{2} \mathrm{R}_{\mathrm{mt}}+\sum_{\mathrm{a}=-\mathrm{w}_{1}}^{\mathrm{w}_{2}} \gamma_{2 \mathrm{a}} \mathrm{D}_{\mathrm{at}}+\varepsilon_{2 \mathrm{t}} \\
& \cdots \\
& \mathrm{R}_{\mathrm{nt}}=\alpha_{\mathrm{n}}+\beta_{\mathrm{n}} \mathrm{R}_{\mathrm{mt}}+\sum_{\mathrm{a}=-\mathrm{w}_{1}}^{\mathrm{w}_{2}} \gamma_{\mathrm{na}} \mathrm{D}_{\mathrm{at}}+\varepsilon_{\mathrm{nt}}
\end{aligned}
$$

where $R_{i t}$ is the total holding period return (including dividends) on security $i$ on day $t, R_{m t}$ is the market return on day $\mathrm{t}, \alpha_{\mathrm{i}}, \beta_{\mathrm{i}}$, and the $\gamma_{\mathrm{ia}}$ are parameters to be estimated, and $\mathrm{D}_{\mathrm{at}}$ are dummy variables set equal to 1 on the a-th announcement day for a given event and to zero otherwise. Stock return data are from the Center for Research in Security Prices (CRSP), with the CRSP equally weighted market return representing $\mathrm{R}_{\mathrm{mt}}$. Event windows for a given event are denoted $\left(-\mathrm{w}_{1},+\mathrm{w}_{2}\right)$, which stands for a window beginning $\mathrm{w}_{1}$ days prior to the event announcement, including the announcement day (day 0 ), and extending $\mathrm{w}_{2}$ days after the announcement.

The disturbance terms, $\varepsilon_{i t}$, are assumed to be independent and identically distributed over-time for a given firm but are allowed to have different variances across equations (heteroskedasticity), i.e., $\mathrm{E}\left(\varepsilon_{\mathrm{it}}{ }^{2}\right)$ $=\sigma_{\mathrm{i}}^{2} \neq \mathrm{E}\left(\varepsilon_{\mathrm{jt}}{ }^{2}\right)=\sigma_{\mathrm{j}}{ }^{2}$. Moreover, the disturbance terms across equations are allowed to be correlated contemporaneously, i.e., $\mathrm{E}\left(\varepsilon_{\mathrm{it}} \varepsilon_{\mathrm{jt}}\right) \neq 0$, but the non-contemporaneous covariances are assumed to be zero, $\mathrm{E}\left(\varepsilon_{\mathrm{it}} \varepsilon_{\mathrm{j}, \mathrm{t}-\mathrm{k}}\right)=0, \mathrm{k}>0$. These are standard assumptions in the literature using the MVRM approach.

The abnormal returns in the MVRM are given by the estimated $\gamma_{\text {ia }}$ parameters. The cumulative abnormal return for firm $\mathrm{i}$ in the $\left(-\mathrm{w}_{1},+\mathrm{w}_{2}\right)$ event window is the estimate $\gamma_{\mathrm{i}}$ given by: 


$$
\gamma_{\mathrm{i}}=\sum_{\mathrm{a}=-\mathrm{w}_{1}}^{\mathrm{w}_{2}} \gamma_{\mathrm{i}, \mathrm{a}}
$$

and the cumulative average abnormal return is the estimate $\bar{\gamma}$, given by

$$
\bar{\gamma}=\frac{1}{\mathrm{~N}} \sum_{\mathrm{i}=1}^{\mathrm{N}} \gamma_{\mathrm{i}}
$$

The primary null hypothesis tested is the following:

Hypothesis: The cumulative average abnormal return is equal to zero: $\bar{\gamma}=0$

The system of equations (1) is estimated separately for each of the industries analyzed in this study. Although this approach implicitly assumes that the residuals are contemporaneously uncorrelated across industries, estimating the models for all industries simultaneously would be infeasible because of inadequate degrees of freedom. Moreover, the industries in the study are expected to react somewhat differently to the passage of TRIA.

Since our hypotheses tests are joint across all firms in the sample, efficient use of the data involves taking into account the cross-sectional covariances among the $\mathrm{N}$ firms through the estimated covariance matrix of residuals (Schipper and Thompson, 1983). Thus, the covariance matrix must be inverted in order to obtain test statistics. Although inversion is possible as long as the number of timeseries observations exceeds the number of firms, Schipper and Thompson (1983) show that the inverted matrix estimate has an inverted Wishart distribution "which has undesirable properties when the number of time-series observations is not greater than twice one plus the number of firms," i.e., the number of time series observations should be: $\mathrm{T}>2 *(\mathrm{~N}+1)$. The number of firms in our industry samples ranges from 28 in construction to nearly 400 in banking. However, we did not consider it advisable to use lengthy estimation periods for our models because of the likelihood that the parameter estimates $\left(\alpha_{i}\right.$ and $\beta_{i}$ ) might not be stable over relatively long periods of time. Accordingly, we decided to limit the total number of firm-level observations in any given sample to 200 firms. This resulted in a reduced sample only for the banking industry. Because larger banks are more likely to be involved in financing high value commercial and industrial loans, which arguably are the ones most likely to be affected by 
terrorism-related issues, we restricted the banking sample to the 200 largest banks in terms of market capitalization. This gave us a maximum estimation period (days prior to the event) of 400 market trading days, or approximately 1.6 years. For industries where $2 *(\mathrm{~N}+1)$ was less than or equal to 250 , we adopted the standard event study estimation period of 250 trading days, or approximately one year. ${ }^{26}$

\subsection{Empirical Results}

The analysis was conducted for a series of event windows for each event listed in Table 2. The windows include our preferred event window for each event (except event 1, where there are two preferred windows) as well as three "standard" windows utilized for each event: $(-1,+1),(-5,+5)$, and $(-$ $10,+10)$. In some cases, the preferred window is the same as one of the standard windows, so only three rather than four event windows are reported. As mentioned, the wider windows are designed to allow for information leakage prior to the event as well as further Congressional negotiations and other information that might be released following the event. For example, the wider windows surrounding the passage of the bill and its signing into law by the President are included because it is likely that the precise meaning of various provisions of the bill and hence their impact on expected future cash flows may not have been known immediately but rather may have emerged after further information was released by government officials. Among other things, regulations from Treasury specifying how the coverage under the Act is to be administered were not forthcoming for several weeks following passage. In interpreting the results, it should be remembered that event 6 , which is focused on the collapse in negotiations and the temporary "death" of the legislation, ought to have a different sign from most of the other events in which information had either an ambiguous or a positive effect on the probability that legislation would pass.

The results of the analysis are provided in Table 3. The table gives the cumulative average abnormal returns (CAAR) for each event and event window covered by the study as well as the p-value for the F-tests of statistical significance and the significance level for each F-test. We also computed the median average abnormal return, which supports the same conclusions as the average.

We first discuss the effect of the passage of TRIA on all of the industries analyzed. This is event

\footnotetext{
${ }^{26}$ The estimation period is 400 days for the overall insurance industry, REITS, and banking, and 250 days for the other industries.
} 
number 12, centered on November 20, 2002. The wider windows for this event also capture the passage of the legislation in the House four business days earlier (November 14). The results for event 12 are summarized in Figure 2, which shows the CAAR results for the $(-1,+1),(-5,+5)$, and $(-10,+10)$ event windows. The results indicate a statistically significant negative response for all event windows for all segments of the insurance industry - P\&C insurers, life insurers, agents and brokers, and the insurance industry total. For example, for the $(-5,+5)$ window $\mathrm{P} \& \mathrm{C}$ insurer stocks on average lost $2.95 \%$ of their value, life insurer stocks lost $4.68 \%$, and agent and broker stocks lost $5.03 \%$. It is somewhat surprising that the impact on life insurers and agents and brokers is stronger than for $\mathrm{P} \& \mathrm{C}$ insurers, the industry segment most directly affected by the Act. This suggests that the market may have been reacting to the general implications of the Act for insurance market efficiency rather than to the specific implications for terrorism insurance coverage. The agent and broker response is especially noteworthy because agents and brokers primarily make their money from commissions on insurance premiums and generally take no underwriting risk. Consequently, the negative response could indicate that the market anticipated lower revenues for agents and brokers following passage of the Act, i.e., that premium revenues for terrorism coverage would have been higher had the government not intervened in the private insurance market.

The average cumulative abnormal returns are also statistically significant and negative in all three event windows shown in Figure 2 for REITs and transportation firms. The CAARs are also negative and statistically significant in the $(-5,+5)$ and $(-10,+10)$ windows for banks. The negative stock price impact for REITs is generally less than for insurers, and the negative reaction for banks is smaller than for insurers in the $(-5,+5)$ window but larger in the $(-10,+10)$ window. Thus, passage of the Act was bad news for REITs, transportation firms, and banks. None of the CAARs is statistically significant for construction firms in any of the windows surrounding $11 / 20 / 2002$. The only statistically significant positive CAAR for any of the industries included in the analysis is for utilities in the $(-4,0)$ window.

There was an additional negative stock price effect for most of the industries included in the study associated with the signing of the bill into law on $11 / 26 / 02$. A negative and significant reaction was registered in all three event windows life insurers, the insurance sector as a whole, REITS, transportation 
firms, and banks, and the reaction was negative and significant in two of three windows for utilities. The $\mathrm{P} \& \mathrm{C}$ industry returns were negative but not statistically significant, and the returns for construction firms were not statistically significant. Thus, the results for both the passage of the Act and the signing of the bill into law provide strong evidence that TRIA was not viewed favorably by securities markets.

We next consider the impact of the other events on specific industries. The stock price reaction for $\mathrm{P} \& \mathrm{C}$ insurers in the $(-1,+1),(-5,+5)$, and $(-10,+10)$ windows for all thirteen events is shown in Figure 3. P\&C stock prices reacted negatively to the majority of news events involving TRIA, and the reaction is statistically significant for at least one of the three windows for events $1,2,4,5,11$, and 12 .

Significant positive CAARs were recorded only in the $(-2,+2)$ window for event 7 and the $(-1,+1)$ window for event 10. Event 7 on June 6, 2002, involved the announcement that a new insurance plan sponsored by Senators Dodd and Schumer "may end Senate stalemate," and thus could be interpreted as a favorable response to forward movement towards passage of the legislation. However, event 10, on October 7 , 2002, was a negative announcement regarding the legislation, indicating continuing disagreement between Democrats and Republicans on the tort liability issue. Thus, there again appears to be very little evidence that any news concerning the passage of terrorism legislation was viewed favorably by the market with respect to $\mathrm{P} \& \mathrm{C}$ insurers.

The results for life insurers are similar to those for $\mathrm{P} \& \mathrm{C}$ insurers for most of the events, paralleling the results for event number 12 shown in Figure 2. Life insurers had a positive stock price response in the $(-5,+5)$ and $(-10,+10)$ windows for event 9 , but the response is significant only for the latter window, which overlaps event 10. Life insurers had a significant positive stock price response in all three windows for event 10 . Because news events for event $9(10 / 02 / 02)$ mention a major lobbying push by life insurers to extend the legislation to cover them, the significant positive response to event 10 may indicate that the life insurers' hopes were still alive in the period surrounding this event (10/07/02). If so, this would provide one of the few indications of a positive stock price response to the bill in the insurance sector. This interpretation is somewhat doubtful, however, in view of fact that the news announcements in connection with event 10 primarily concerned disagreements over tort reform. Insurance agents and 
brokers had a statistically significant negative stock price response in at least one window for events 1,2 , 4, 5, 9, and 12 and had no significant positive stock price response in any of the event windows studied.

The results for the REITs generally parallel those for P\&C and life insurers. The REITS had statistically significant negative stock price responses in at least one window for all events except 6, 7, and 8 and had statistically significant negative responses for at least three windows for events $1,2,9,10$, 11, 12, and 13. REITs registered statistically significant positive returns in all windows for event 6 , $12 / 20 / 01$, the date when negotiations over the bill collapsed due to the tort liability features, and the effort to enact the legislation in 2001 ended. Thus, movements toward a federal role in terrorism insurance generally were bad news for the REITs. This could reflect the view that federal efforts would impede a more efficient private market solution to the problem or a Samaritan's dilemma effect.

Bank stocks registered statistically significant negative CAARs in at least one window for events $1,2,3,4,5,9,11,12$, and 13. Banks had significant positive CAARs in response to the event 6 announcement on 12/20/01 that agreement on the bill had collapsed and also had a significant positive response in all three windows for event 10. These results are consistent with TRIA being generally bad news for banks. The banks' significant positive stock price response to events 7 and 8 , both of which involved favorable news about the passage of a Senate bill, is perhaps inconsistent with this interpretation, but on balance the legislation appears to have been viewed as generally adverse for banks. Utilities generally had a more mixed response to TRIA events than did the financial institutions covered by the study. In the preferred event window for the passage of the Act $(-4,0)$, utilities had a significant positive CAAR of $2.39 \%$, although the $(-1,+1)$ and $(-5,+5)$ responses to the signing of the bill into law were significant and negative (-1.90 and $-2.32 \%$, respectively). Utilities also had significant positive CAARs for at least one window in response to events $3,4,6,11$, and 12 but had significant negative CAARs in response to events $5,7,9,10$, and 13 . Thus, it is difficult to draw any firm conclusions about the overall response of the utilities to the TRIA events, especially in view of the seemingly contradictory response to the passage of the Act and the signing of the bill by the President.

The results with the transportation stocks are also somewhat puzzling, although for this industry 
the response to the passage of the legislation and the Presidential signing were both consistently negative and significant. Nevertheless, the transportation stocks had significant positive responses to several events, including $1,3,4,5,7,8$, and 9 . Thus, the results for this industry also are somewhat inconclusive, although the negative reaction to the bill's passage and Presidential signing appears unambiguous.

The construction industry showed by far the weakest response to the TRIA events, perhaps reflecting the fact that construction had the smallest sample size for all industries included in the study, ranging from 21 to 28 firms. There are very few statistically significant CAARs for the construction industry for any of the TRIA events, although the majority of the CAARs for construction are positive. Construction firms registered a significant positive CAAR in the $(-10,+10)$ window for event 6 , a negative news event for TRIA, but also registered significant positive CAARS for events 7 and 9, which were generally favorable events for TRIA. Thus, it is difficult to draw conclusions about the effect of TRIA on the construction industry, except perhaps that the strong positive response predicted by the President's remarks at the bill-signing ceremony is not evident.

\subsection{Economic Indicators in the Periods Preceding and Following $9 / 11$ and TRIA}

In this section, we look at some other economic indicators during the periods preceding and following the World Trade Center attacks on 9/11/2001 and the passage of TRIA in November 2002. Because there are many factors that drive macro-economic time series and we cannot measure the precise response to specific daily events as in the case of stock prices, the purpose of this analysis is primarily to provide an economic context for the period when TRIA was being considered and eventually enacted. Information on terrorism insurance pricing and take-up rates under TRIA is mostly anecdotal at this stage. However, the consensus of opinion seems to be that prices are quite variable across the industry and take-up rates are generally low, perhaps in the range of $20 \%$. In a survey of insurance brokers released in March 2003, the Council of Insurance Agents and Brokers (CIAB) (2003) reported that $19 \%$ of small brokerage customers, $22 \%$ of medium size firms, and $29 \%$ of large firms were purchasing terrorism insurance. A report by Moody's Investors Service indicated that "five months after its passage, the Terrorism Risk Insurance Act (TRIA) has begun to have its intended effect. Rates for 
terrorism coverage have clearly abated ... Even for office properties in Manhattan, there has been an improvement in the availability and affordability of terrorism insurance" (Philipp, 2003). Of course, prices may have fallen to some degree even in the absence of TRIA due to new capital entering the industry, insurer learning about pricing terrorism coverage, or just due to competition. Such price reductions would be consistent with experience following earlier catastrophes such as Hurricane Andrew.

Information on commercial $\mathrm{P} \& \mathrm{C}$ insurance prices is available from quarterly surveys conducted by the CIAB (e.g., CIAB 2003a). The surveys ask the agents and brokers who are members of CIAB to indicate the average price increases for their commercial clients for a variety of $\mathrm{P} \& \mathrm{C}$ coverages. The CIAB survey responses from the fourth quarter of 1999 through the third quarter of 2003 are summarized in Figure 4. The figure shows the average price increases reported by CIAB respondents for five commercial lines $\mathrm{P} \& \mathrm{C}$ coverages - commercial auto, workers' compensation, commercial property, general liability, and umbrella insurance coverage. Terrorism insurance price increases are shown for the more recent quarters when this coverage was included in the survey. Of the lines shown in the figure, commercial auto is least likely to be affected by terrorism risk and terrorism, and the commercial property and umbrella coverages are most likely to be affected. The figure shows that commercial $\mathrm{P} \& \mathrm{C}$ prices were generally trending upwards during 2000 and 2001, even prior to the WTC attacks, as part of a general "hard market" phase of the P\&C underwriting cycle. ${ }^{27}$ Prices rose sharply following the WTC attacks, with the increases being especially pronounced for the commercial property and umbrella coverages. The price hikes began to taper off sharply beginning in the third quarter of 2002, which is before TRIA, suggesting that the market forces were already beginning to work, and the average price increase for commercial property was nearly zero in the third quarter of 2003 . Terrorism insurance price increases closely track those for commercial property during the most recent four quarters.

\footnotetext{
${ }^{27}$ Property-casualty insurance is subject to an "underwriting cycle," characterized by alternating periods of "hard" and "soft" markets. During hard markets, coverage availability is restricted and prices increase, while during a soft market phase coverage is readily available and prices decline. Several theories have been advanced to explain the existence of underwriting cycles. A common theme is that informational asymmetries between insurers and capital markets make it difficult for insurers to raise capital following a loss shock. Thus, insurers tend to hoard capital during profitable periods, creating excess capacity that puts downward pressure on prices. Following a loss or investment shock, when capital is depleted, prices tend to increase as buyers compete for scarce capacity. For a review of underwriting cycle theory, see Harrington and Niehaus (2001).
} 
The sharply lower rates of price increase from the third quarter of 2002 through the present shown in Figure 4 coincide with the enactment and implementation of TRIA and may indicate that the Act had a favorable impact on insurance markets. However, the observed trends also would be consistent with most of the increased loss expectations arising from 9/11 having already been priced into commercial P\&C policies by the middle of 2002, such that the need for further price increases abated in the absence of new information about terrorism risk.

To investigate macro-economic changes in sectors potentially affected by terrorism insurance, we analyze two construction series - the value of new private commercial construction put in place and total non-farm private sector construction employment. These series are shown in Figures 5 and 6, respectively. The value of new office and manufacturing construction put in place trended mostly downward during the period January 2001 through August 2003, but retail and health care construction did considerably better. There is little evidence of a rebound in office construction following the enactment of TRIA, although retail construction accelerated during the last three months shown in Figure. Total non-farm private sector construction employment increased steadily throughout most of the 1990s before leveling off in early 2001. This series declined during most of 2002 and did not rebound following the enactment of TRIA. We also looked at commercial construction loans of large commercial banks, which remained relatively constant during the fourth quarter of 2002 and the first quarter of 2003, before declining in the second quarter of 2003 and perhaps beginning a modest upward trend in recent months.

We also looked at two market value series from sectors that may have been affected by TRIA, the national commercial property total return series compiled by National Council of Real Estate Investment Fiduciaries (NCREIF) and the NAREIT monthly return series for equity REITs specializing in the office sector. The NCREIF Property Index is one of the most widely used performance measures for institutionally held private real estate in the U.S., including most major types of commercial real estate such as offices, malls, and warehouses. We analyzed total returns on both the overall NCREIF index and the component index for office properties. Both of the NCREIF return series declined significantly following $9 / 11$ but then rebounded somewhat beginning in the second quarter of 2002. Office sector 
returns actually declined in the quarter following the enactment of TRIA but then rebounded later in 2003. The NAREIT office sector total return index showed significantly better performance, post TRIA, increasing steadily for most of 2003. Therefore, we find some evidence of a recovery in the commercial real estate sector during recent periods. However, an official at NAREIT indicated that the recovery in the real estate market was primarily due to factors other than TRIA. ${ }^{28}$ Thus, the macro data provide very little evidence of a surge in economic activity associated with the passage of TRIA.

\section{5. $\underline{\text { Conclusions }}$}

This paper investigates the effects of the Terrorism Risk Insurance Act of 2002 (TRIA) on the industries most likely to be affected by the Act - property-casualty insurance, life insurance, insurance agents and brokers, banking, construction, real estate investment trusts, transportation, and utilities. We conduct an event study analysis which analyzes the stock price reaction of firms in the affected industries to news announcements concerning the events leading up to and including passage of the legislation and its signing into law by the President. We also investigate several macro-economic time series to provide an economic context for the consideration and enactment of TRIA.

The event study results indicate that the stock price effect of TRIA on the affected industries was predominantly negative. For the two final events - Senate passage of the Act (November 20, 2002) and the signing of the bill into law (November 26, 2002) - the stock price effect was significantly negative in most event windows for insurance companies, REITs, transportation firms, and banks. There was a significant positive stock price effect for utilities in the days preceding passage of the Act, but the utilities industry responded negatively to the signing of the bill into law. There were no significant effects for the construction industry for the two ultimate events. Stock prices in the affected industries also responded negatively to most of the other events included in the analysis. Hence, the evidence clearly does not support the view that TRIA was good news in the market value sense for the affected industries.

We offer three primary explanations for the generally negative impact of TRIA. The first, which primarily concerns the property-casualty insurance industry, is that the primary effect of the Act on

\footnotetext{
${ }^{28}$ Conversation with Steven Wechsler, National Association of Real Estate Investment Trusts, December 2003.
} 
insurers was to eliminate the option not to offer terrorism insurance and to expose insurers to potential liability under the Act's deductible and copayment provisions. Because insurance markets are generally competitive, the price of terrorism coverage sold under the Act would be expected to cover the present value of loss and expense cash flows plus a fair profit. Insurers would not be expected to be able to earn rents by pricing the expected value of anticipated federal reinsurance payments into terrorism insurance premiums. Thus, terrorism insurance under TRIA could be expected to be at best a zero net present value project for the property-casualty industry and could create a net negative impact to the extent that federal intervention reduces insurance market efficiency.

A second possible explanation for the generally adverse effects of TRIA on affected stocks is a type of "Samaritan's dilemma" problem. That is, the Act may have reduced market expectations with respect to future federal assistance for firms and industries affected by terrorist events. The market thus may have viewed the program as the substitution in whole or in part of a carefully circumscribed federal reinsurance program for a potentially more open-ended implicit government commitment.

The third explanation for the negative effects of TRIA on stock prices is that the legislation may have created insurance market inefficiencies by preventing or delaying the development of more efficient private market mechanisms for financing terrorism losses. Experience with natural catastrophes has shown that insurance markets tend to rebound following catastrophic loss events as new capital enters the industry and insurers gain experience with pricing large loss events. By potentially impeding such private market developments, TRIA may in fact have worsened conditions in insurance markets. Such an effect is probably attributable to the design of TRIA, which resulted in more intrusive government intervention in the insurance market than might have been desirable under a purely market-enhancing theory of government involvement. Thus, to the extent that policymakers conclude that future government intervention in the terrorism insurance market is necessary, any such program should be designed to assist rather than hinder private market efforts to solve the terrorism insurance problem. 


\section{$\underline{\text { References }}$}

Barnes, L., 2002, A closer look at Britain’s Pool Re, Risk Management 49, 18-23.

Bhagat, S. and R. Romano, 2002, Event studies and the law, part II: empirical studies of corporate law, American Law and Economics Review 4, 380-423.

Binder, J.J., 1985, On the use of the multivariate regression model in event studies, Journal of Accounting Research 23, 370-383.

Braun, A., R.M. Todd, and N. Wallace, 1998, The role of damage-contingent contracts in allocating the risks of natural catastrophes, Federal Reserve Bank of Minneapolis Working Paper No. 586D.

Brown, J.R., R.S. Kroszner, and B.H. Jenn, 2002, Federal terrorism risk insurance, National Tax Journal $55,647-657$.

Brown, S. and J.B. Warner, 1985, Using daily stock returns: The case of event studies, Journal of Financial Economics 14, 3-33.

Buchanan, J.M., 1975, The Samaritan's dilemma, in: Edmund S. Phelps, ed., Altruism, morality, and economic theory (Russell Sage Foundation, New York).

Cornett, M.M. and H. Tehranian, 1990, An examination of the impact of the Garn-St. Germain depository institutions act of 1982 on commercial banks and savings and loans, Journal of Finance 45, 95-111.

Council of Insurance Agents \& Brokers, 2003, 2003 terrorism insurance survey (Washington, DC).

Cowan, A.R., 2002, Eventus 7 user's guide, revised edition (Cowan Research, Ames, IA).

Cummins, J.D., S.E. Harrington, and R.W. Klein, 1991, Cycles and crises in property/casualty insurance: causes and implications for public policy (National Association of Insurance Commissioners, Kansas City, MO).

Cummins, J.D., and C.M. Lewis, 2003, Catastrophic events, parameter uncertainty and the breakdown of implicit long term contracting: The case of terrorism insurance, Journal of Risk and Uncertainty 26, 153178.

Cutler, D.M., 1988, Tax reform and the stock market: An asset price approach, American Economic Review 78, 1107-1117.

Doherty, N.A., J. Lamm-Tennant, and L.T. Starks, 2003, Insuring September $11^{\text {th }}$ : Market recovery and transparency, Journal of Risk and Uncertainty 26, 179-199.

Froot, K.A., 2001, The market for catastrophe risk: A clinical examination, Journal of Financial Economics 60, 529-571.

Froot, K.A. and P.G.J. O'Connell, 1999, The pricing of U.S. catastrophe reinsurance, in: Kenneth Froot, ed., The financing of catastrophe risk (University of Chicago Press, Chicago), 195-227.

Guy Carpenter, Inc., 2003, The world catastrophe reinsurance market: 2003 (New York).

Harrington, S.E. and G. Niehaus, 2001, Volatility and underwriting cycles, in: G. Dionne, ed., Handbook 
of insurance (Kluwer Academic Publishers, Boston), 657-686.

Jaffee, D. and T. Russell, 1997, Catastrophe insurance, capital markets, and uninsurable risks, Journal of Risk and Insurance 64, 205-230.

James, C., 1983, An analysis of intra-industry differences in the effect of regulation: The case of deposit rate ceilings, Journal of Monetary Economics 12, 417-432.

Joskow, P.L., and L. McLaughlin, 1991, McCarran-Ferguson act reform: More competition or more regulation? Journal of Risk and Uncertainty 4, 373-401.

Lewis, C.M. and K.C. Murdock, 1999, Alternative means of redistributing catastrophic risk in a national risk management system, in: Kenneth Froot, ed., The financing of catastrophe risk (University of Chicago Press, Chicago), 51-88.

Lewis, C.M. and K.C. Murdock, 1996, The role of government contracts in discretionary reinsurance markets for natural disasters, Journal of Risk and Insurance 63, 567-597.

MacKinlay, A.C., 1997, Event studies in economics and finance, Journal of Economic Literature 35, 1239.

Musgrave, R.A. and P.B. Musgrave, 1984, Public finance in theory and practice, $4^{\text {th }}$ ed. (McGraw-Hill, New York).

National Association of Insurance Commissioners, 1994, Monitoring competition: A means of regulating the property and liability insurance business (Kansas City, MO).

National Association of Real Estate Investment Trusts, 2003, Insurance survey (Washington, DC).

Peltzman, S., 1989, The economic theory of regulation after a decade of deregulation, Brookings Papers on Economic Activity: Microeconomics, 1-41.

Philipp, T., 2003, Up and down credit signals in cmbs, Mortgage Banking 63, 48-52.

Reinsurance Association of America, 2002, Summary of HR 3210, Senate compromise draft legislation and insurance industry draft legislation on federal terrorism, Washington, DC.

Schipper, K. and R. Thompson, 1983, The impact of merger-related regulations on the shareholders of acquiring firms, Journal of Accounting Research 21, 184-221.

Schumann, L., 1988, State regulation of takeovers and shareholder wealth: The case of New York's 1985 takeover statutes, Rand Journal of Economics 19, 557-567.

Schwert, G.W., 1981, Using Financial data to measure the effects of regulation, Journal of Law and Economics 25, 121-145.

Stigler, G., 1971, The theory of economic regulation, Bell Journal 2, 3-21.

Woo, G., 2003, Quantifying insurance terrorism risk, paper presented at National Bureau of Economic Research Insurance Project Meeting, Cambridge, MA. 
Table 1

Summary of Key Provisions of Terrorism Insurance Proposals

\begin{tabular}{|c|c|c|c|c|}
\hline & $\begin{array}{c}\text { Administration } \\
\text { Proposed 10/15/01 }\end{array}$ & $\begin{array}{c}\text { House } \\
\text { Passed 11/29/01 }\end{array}$ & $\begin{array}{c}\text { Senate } \\
\text { Passed 6/18/02 }\end{array}$ & $\begin{array}{c}\text { TRIA } 2002 \\
\text { Signed 11/26/02 }\end{array}$ \\
\hline Duration & - $\quad$ Through 2004 & $\begin{array}{l}\text { Through } 2002, \text { with } \\
\text { extension through } 2004 \text { at } \\
\text { discretion of Treasury }\end{array}$ & $\begin{array}{l}\text { Terminate after one year, } \\
\text { with one year extension at } \\
\text { discretion of Treasury }\end{array}$ & - $\quad$ Through 2005 \\
\hline $\begin{array}{l}\text { Government's } \\
\text { share of risk }\end{array}$ & $\begin{array}{ll}\text { - } & \text { 2002: } 80 \% \text { of first } \$ 20 \\
& \text { bil., } 90 \% \text { of excess } \\
\text { - } \quad 2003: 50 \% \text { of losses from } \\
\quad \$ 10-20 \text { bil., } 90 \% \text { of excess } \\
\text { - } \quad 2004: 50 \% \text { of losses from } \\
\quad \$ 20-40 \text { bil., } 90 \% \text { of excess } \\
\end{array}$ & $\begin{array}{l}\text { For industry wide trigger, } \\
90 \% \text { of losses after first } \$ 5 \\
\text { million } \\
\text { For individual insurer } \\
\text { trigger, } 90 \% \text { of losses after } \\
10 \% \text { of written premiums }\end{array}$ & $\begin{array}{l}\text { - } \quad 80 \% \text { above individual } \\
\text { company deductible but } \\
\text { below industry deductible } \\
\text { - } 90 \% \text { of losses above } \\
\text { industry deductible }\end{array}$ & $\begin{array}{l}90 \% \text { above insurer } \\
\text { deductible }\end{array}$ \\
\hline $\begin{array}{c}\text { Industry } \\
\text { Deductible }\end{array}$ & 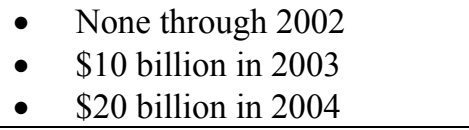 & - $\quad \$ 5$ million for industry & $\begin{array}{ll}\text { - } & \$ 10 \text { billion in first year } \\
- & \$ 15 \text { billion if extended for } \\
& \text { one additional year }\end{array}$ & $\begin{array}{ll}\text { - } & \$ 10 \text { billion in } 2003 \\
\text { - } & \$ 12.5 \text { billion in } 2004 \\
\text { - } & \$ 15 \text { billion in } 2005 \\
\end{array}$ \\
\hline $\begin{array}{l}\text { Individual } \\
\text { Insurer } \\
\text { Deductible }\end{array}$ & - $\quad$ None & $\begin{array}{l}10 \% \text { of premiums for } \\
\text { individual insurer }\end{array}$ & $\begin{array}{l}\text { Market share of direct } \\
\text { written premiums times } \\
\text { \$industry deductible }\end{array}$ & $\begin{array}{ll}\text { - } & 7 \% \text { of direct earned } \\
\text { premiums in } 2003 \\
\text { - } & 10 \% \text { in } 2004 \\
\text { - } & 15 \% \text { in } 2005 \\
\end{array}$ \\
\hline Aggregate Cap & - $\$ 100$ billion & - $\quad \$ 100$ billion & - $\$ 100$ billion & - $\quad \$ 100$ billion \\
\hline $\begin{array}{l}\text { Recoupment: } \\
\text { Ex-post } \\
\text { Assessments }\end{array}$ & - None & $\begin{array}{l}\text { - Up to } \$ 5 \text { bil of first } \$ 20 \text { bil } \\
\text { repaid via industry-wide } \\
\text { assessments (not exceeding } \\
3 \% \text { of annual premiums) } \\
\text { - Assistance beyond } \$ 20 \text { bil } \\
\text { repaid via premium } \\
\text { surcharges }\end{array}$ & - $\quad$ None & 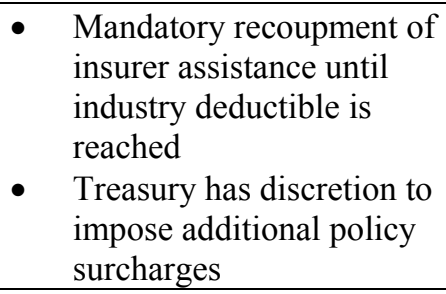 \\
\hline $\begin{array}{c}\text { Liability } \\
\text { Provisions }\end{array}$ & $\begin{array}{ll}\text { - } & \text { No punitive damages } \\
\text { - } & \text { Proportional non-economic } \\
\text { damages } \\
\text { - } \\
\text { Consolidation of claims } \\
\text { into single federal } \\
\text { jurisdiction }\end{array}$ & $\begin{array}{ll}\text { - } & \text { No punitive damages } \\
\text { - } & \text { Proportional non-economic } \\
\text { damages }\end{array}$ & $\begin{array}{ll}- & \text { Federal cause of action } \\
- & \text { Punitive damages not } \\
\text { treated by TRIA as insured } \\
\text { losses }\end{array}$ & $\begin{array}{ll}- & \text { Punitive damages not } \\
\text { treated by TRIA as insured } \\
\text { losses } \\
\text { - } & \text { Federal jurisdiction }\end{array}$ \\
\hline
\end{tabular}


Table 2

Event Study Dates

\begin{tabular}{|c|c|c|}
\hline Event & $\begin{array}{l}\text { Central Event Date } \\
\text { (Event Window) }\end{array}$ & Description of Event \\
\hline 1 & $\begin{array}{l}\text { Wednesday } \\
10 / 10 / 01 \\
(-2,+2)\end{array}$ & $\begin{array}{l}\text { News reports that AIA proposal is receiving little support from key } \\
\text { lawmakers. Chmn. Oxley "unenthusiastic," Sen. Gramm "would not } \\
\text { support," Treasury sources float the idea of a backstop with a } \$ 10 \\
\text { billion trigger point, which industry thinks is too high. }\end{array}$ \\
\hline 2 & $\begin{array}{l}\text { Monday } \\
10 / 15 / 01 \\
(0,+1)\end{array}$ & $\begin{array}{l}\text { "The White House today weighed in with its own proposal } \\
\text { guaranteeing reinsurance coverage." Senior White House officials } \\
\text { said the administration will "push for passage of legislation this year } \\
\text { to authorize the new program."2 Lays out specific program of } \\
\text { government/industry cost-sharing to end in } 2005 \text {. }\end{array}$ \\
\hline 3 & $\begin{array}{c}\text { Thursday } \\
11 / 01 / 01 \\
(-1,+1)\end{array}$ & $\begin{array}{l}\text { House and Senate legislators engaged "in a race over terrorism } \\
\text { insurance coverage." In the House, Financial Services Cmte Chair } \\
\text { Oxley introduces bill including recoupment of costs. Details emerge } \\
\text { about an hour later on a Senate Banking Cmte bill that had been } \\
\text { worked "extensively" with the Treasury Department. }{ }^{4} \text { House and } \\
\text { Senate bills differ substantially, but both are moving ahead. }\end{array}$ \\
\hline 4 & $\begin{array}{l}\text { Thursday } \\
11 / 8 / 01 \\
(-1,+1)\end{array}$ & $\begin{array}{l}\text { After a "less than promising start" on the markup of legislation the } \\
\text { day before, the House Financial Service Cmte overwhelmingly } \\
\text { approves HR } 3210 .^{6} \text { But it is also becoming increasingly clear that the } \\
\text { House and Senate bill are "light years apart,", suggesting potential } \\
\text { difficulties ahead. }\end{array}$ \\
\hline 5 & $\begin{array}{l}\text { Thursday } \\
11 / 29 / 01 \\
(-1,+2)\end{array}$ & $\begin{array}{l}\text { House bill (HR 3210) passes 227-193. Three Senate bills introduced } \\
\text { by Senate Commerce Chmn Hollings, Banking ranking member } \\
\text { Gramm, and Commerce ranking member McCain. Industry appears to } \\
\text { line up behind Gramm bill. }\end{array}$ \\
\hline 6 & $\begin{array}{l}\text { Thursday } \\
12 / 20 / 01 \\
(0,+1)\end{array}$ & $\begin{array}{l}\text { As late as Wednesday, } 12 / 19 \text {, prospects for Senate passage of } \\
\text { terrorism bill looked strong. }{ }^{8} \text { Reports during the day on } 12 / 20 \text { suggest } \\
\text { that all sides were making strong attempt to work through } \\
\text { disagreements. Late in the day, agreement collapses due to } \\
\text { differences over tort liability features, and it becomes clear that the } \\
\text { legislation is dead. The Senate adjourns the next day with no action } \\
\text { on the bill. }\end{array}$ \\
\hline 7 & $\begin{array}{l}\text { Friday } \\
6 / 7 / 02 \\
(-2,+2)\end{array}$ & $\begin{array}{l}\text { On Thursday } 6 / 6 / 02 \text {, reports surface that a new insurance plan, to be } \\
\text { offered by Senators Dodd \& Schumer, may "end Senate stalemate." } \\
\text { Legislation formally introduced on June } 7 \text {. The bill placed on Senate } \\
\text { calendar and rules invoked to allow it to "bypass the committee circuit } \\
\text { and be brought directly to the floor.",10 }\end{array}$ \\
\hline 8 & $\begin{array}{l}\text { Thursday } \\
6 / 19 / 02 \\
(-5,+2)\end{array}$ & $\begin{array}{l}\text { After several days of pointed debate that started on } 6 / 13 \text {, the Senate } \\
\text { invoked cloture to close debate on the bill and set for a final vote. By } \\
\text { the end of the day on } 6 / 18 \text {, the Senate approved the bill } 84-14 \text {. }\end{array}$ \\
\hline
\end{tabular}

${ }^{1}$ Congress Daily, 10-10-2001: “GOP Wary of Federal Terrorist Reinsurance Proposal” by Pamela Barnett

${ }^{2}$ Congress Daily, 10-15-2001: “Administration Unveils Details of Reinsurance Proposal” by Keith Koffler

${ }^{3}$ Congress Daily, 11-01-2001: "House, Senate Panels Compete over Terrorism Insurance Bill” by Pamela Barnett

${ }^{4}$ Congress Daily, 11-02-2001: “Tough House-Senate Negotiations Seen on Reinsurance Bill” by Pamela Barnett

${ }^{5}$ Congress Daily, 11-07-2001: "Reinsurance Markup Of to Shaky Start in House Panel” by Pamela Barnett

${ }^{6}$ Congress Daily, 11-08-2001: “House, Senate Dems Work on Reinsurance Differences” by Pamela Barnett

${ }^{7}$ Ibid

${ }^{8}$ Congress Daily, 12-19-2001: "Daschle Expects Terrorism Insurance Bill by End of Week"

${ }^{9}$ Congress Daily, 6-06-2002: "New Terrorism Insurance Plan May End Stalemate"

${ }^{10}$ Congress Daily, 6-07-2002: "Dodd, Schumer Introduce Measure on Terrorism Insurance" 


\begin{tabular}{|c|c|l|}
\hline 9 & $\begin{array}{c}\text { Wednesday } \\
10 / 02 / 02 \\
(-1,+1)\end{array}$ & $\begin{array}{l}\text { This week was comprised of a major push by the White House and } \\
\text { supporters of the legislation to move it along. Events included a major } \\
\text { Presidential media event, public letters from business groups, etc. } \\
\text { News events also included major push by life insurance companies to } \\
\text { extend the legislation to cover them. Reports indicate that "optimism } \\
\text { high for agreement" and key legislative leaders suggest that a deal will } \\
\text { be reached. }\end{array}$ \\
\hline 10 & $\begin{array}{c}\text { Monday } \\
10 / 07 / 02 \\
(-1,+1)\end{array}$ & $\begin{array}{l}\text { Key Republican negotiators rejected Senate Democrat's "final offer" } \\
\text { on the liability provisions. White House also indicates desire for } \\
\text { stronger tort provisions. }\end{array}$ \\
\hline 11 & $\begin{array}{c}\text { Thursday } \\
10 / 17 / 02 \\
(-1,+1)\end{array}$ & $\begin{array}{l}\text { As late as Tuesday 10/15, terrorism talks remained "stalled over } \\
\text { liability."12 After all-night "marathon" negotiations, final agreement } \\
\text { was finally reached between House and Senate conferees. House } \\
\text { adjourns for November elections, so further movement delayed until } \\
\text { November. }\end{array}$ \\
\hline 12 & $\begin{array}{c}\text { Wednesday } \\
11 / 20 / 02 \\
(-4,0)\end{array}$ & $\begin{array}{l}\text { On 11/14, the reinsurance bill "snapped to life."13 House conferees } \\
\text { signed conference report, full House approved legislation. Senate } \\
\text { action was expected soon, and Senate passage came late in the } \\
\text { evening (after the close of the markets) on Tuesday November } 19 \text { with } \\
\text { an } 86-11 \text { vote. }\end{array}$ \\
\hline 13 & $\begin{array}{l}\text { President George W. Bush signs the Terrorism Risk Insurance Act } \\
\text { into law, making strong remarks about its projected favorable } \\
\text { economic impact at the signing ceremony. }\end{array}$ \\
\hline
\end{tabular}

${ }^{11}$ Congress Daily, 10-03-2002: "Optimism High for Agreement on Terrorism Insurance Bill” by Pamela Barnett. ${ }^{12}$ Congress Daily, 10-15-2002: “Terrorism Insurance Talks Remain Stalled over Liability” by Pamela Barnett ${ }^{13}$ Congress Daily, 11-14-2002: "Reinsurance, Bankruptcy Snap To Life” by Pamela Barnett. ${ }^{14}$ Congress Daily, 11-20-2002: "Senate Ends $107^{\text {th }}$ Odyssey with Homeland, Reinsurance Votes" by Brody Mullins and Pamela Barnett. 
Table 3: Results of Multivariate Regression Model Analysis

\begin{tabular}{|c|c|c|c|c|c|c|c|c|c|c|c|c|c|c|}
\hline \multirow[b]{2}{*}{ No. } & \multirow[b]{2}{*}{ Windows } & \multirow[b]{2}{*}{ Hypotheses } & \multicolumn{3}{|c|}{ P\&C } & \multicolumn{3}{|c|}{ Life } & \multicolumn{3}{|c|}{ Agents\&Brokers } & \multicolumn{3}{|c|}{ InsuranceTotal } \\
\hline & & & $\mathbf{N}$ & CAAR & Prob $>F$ & $\mathbf{N}$ & CAAR & Prob>F & $\mathbf{N}$ & CAAR & Prob>F & $\mathbf{N}$ & CAAR & Prob>F \\
\hline \multirow[t]{5}{*}{1} & $(-2,+2)$ & CAAR $=0$ & \multirow[t]{5}{*}{78} & $-2.41 \%$ & $0.0232^{*}$ & \multirow[t]{5}{*}{39} & $-3.51 \%$ & $0.0007^{\star \star \star}$ & \multirow[t]{5}{*}{26} & $-3.47 \%$ & $0.0439^{*}$ & \multirow[t]{5}{*}{192} & $-4.08 \%$ & $0.0001^{* \star \star}$ \\
\hline & $(-5,+1)$ & CAAR $=0$ & & $-3.75 \%$ & $0.0049^{* *}$ & & $-4.64 \%$ & $0.0006^{* * *}$ & & $-0.26 \%$ & 0.9027 & & $-5.29 \%$ & $0.0001^{* * *}$ \\
\hline & $(-1,+1)$ & CAAR=0 & & $-0.99 \%$ & 0.2242 & & $-1.37 \%$ & $0.0812 \$$ & & $-1.95 \%$ & 0.1422 & & $-2.10 \%$ & $0.0003^{* * *}$ \\
\hline & $(-5,+5)$ & CAAR $=0$ & & $-4.40 \%$ & $0.0104^{*}$ & & $-8.20 \%$ & $0.0001^{* \star *}$ & & $-2.14 \%$ & 0.4311 & & $-7.83 \%$ & $0.0001^{* * *}$ \\
\hline & $(-10,+10)$ & CAAR $=0$ & & $-1.07 \%$ & 0.6751 & & $-8.21 \%$ & $0.0033^{* *}$ & & $1.82 \%$ & 0.6488 & & $-6.97 \%$ & $0.0007^{* * *}$ \\
\hline \multirow[t]{4}{*}{2} & $(0,+1)$ & CAAR $=0$ & \multirow[t]{4}{*}{78} & $-0.05 \%$ & 0.9319 & \multirow[t]{4}{*}{39} & $-1.81 \%$ & $0.0037^{\star *}$ & \multirow[t]{4}{*}{26} & $-0.50 \%$ & 0.6394 & \multirow[t]{4}{*}{192} & $-1.07 \%$ & $0.0144^{*}$ \\
\hline & $(-1,+1)$ & CAAR $=0$ & & $-0.84 \%$ & 0.289 & & $-3.11 \%$ & $0.0001^{* * *}$ & & $-1.38 \%$ & 0.293 & & $-2.31 \%$ & $0.0001^{* * *}$ \\
\hline & $(-5,+5)$ & CAAR $=0$ & & $-4.15 \%$ & $0.0131^{*}$ & & $-7.34 \%$ & $0.0001^{* * *}$ & & $-5.88 \%$ & $0.0291^{*}$ & & $-8.08 \%$ & $0.0001^{* * *}$ \\
\hline & $(-10,+10)$ & CAAR $=0$ & & $-8.51 \%$ & $0.0008^{* * *}$ & & $-12.39 \%$ & $0.0001^{* * *}$ & & $-5.45 \%$ & 0.1741 & & $-14.37 \%$ & $0.0001^{* * *}$ \\
\hline 3 & $(-1,+1)$ & CAAR $=0$ & 78 & $0.85 \%$ & 0.3001 & 39 & $1.26 \%$ & $0.0977 \$$ & 26 & $-0.01 \%$ & 0.9895 & 192 & $0.66 \%$ & 0.2081 \\
\hline & $(-5,+5)$ & CAAR $=0$ & & $-0.86 \%$ & 0.6052 & & $-0.46 \%$ & 0.7723 & & $-4.05 \%$ & 18 & & $-1.67 \%$ & 0.131 \\
\hline & $(-10,+10)$ & CAAR $=0$ & & $-2.81 \%$ & 0.253 & & $-3.19 \%$ & 0.188 & & $-5.28 \%$ & 18 & & $-4.46 \%$ & $0.0084^{* *}$ \\
\hline 4 & $(-1,+1)$ & CAAR $=0$ & 78 & $-2.35 \%$ & $0.0192^{*}$ & 39 & $-1.61 \%$ & $0.0295^{*}$ & 26 & $-2.81 \%$ & $0.0461^{*}$ & 192 & $-2.46 \%$ & $0.0001^{* * *}$ \\
\hline & $(-5,+5)$ & CAAR $=0$ & & $-2.63 \%$ & 0.2011 & & $1.78 \%$ & 0.2508 & & $-2.65 \%$ & 24 & & $5 \%$ & 0.1668 \\
\hline & $(-10,+10)$ & CAAR $=0$ & & $-3.84 \%$ & 0.2041 & & $-1.52 \%$ & 0.5154 & & -2 & 0.473 & & $2 \%$ & 028 \\
\hline 5 & $(-1,+2)$ & CAAR $=0$ & 77 & $0.27 \%$ & 0.8309 & 39 & $0.70 \%$ & 0.554 & 26 & $-1.24 \%$ & 582 & 190 & $-0.44 \%$ & 865 \\
\hline & $(-1,+1)$ & \begin{tabular}{|l|} 
CAAR $=0$ \\
\end{tabular} & & $-0.41 \%$ & 0.7089 & & $0.64 \%$ & 0.5037 & & $-0.93 \%$ & 85 & & $2 \%$ & 511 \\
\hline & $(-5,+5)$ & CAAR $=0$ & & $-4.79 \%$ & $0.0337^{*}$ & & $1.60 \%$ & 0.46 & & $-4.27 \%$ & 0.1396 & & $-5.32 \%$ & $0.0001^{* * *}$ \\
\hline & $(-10,+10)$ & CAAR $=0$ & & $-7.14 \%$ & $0.0288^{*}$ & & $2.15 \%$ & 0.5442 & & $-9.19 \%$ & $74^{*}$ & & $-8.78 \%$ & $0.0001^{* * *}$ \\
\hline 6 & $(0,+1)$ & CAAR $=0$ & 76 & $-0.56 \%$ & 0.5196 & 38 & $-0.34 \%$ & 0.5369 & 26 & $-0.30 \%$ & 0.7902 & 191 & $-0.17 \%$ & 0.6764 \\
\hline & $(-1,+1)$ & \begin{tabular}{|l|} 
CAAR $=0$ \\
\end{tabular} & & $0.10 \%$ & 0.9227 & & $-0.04 \%$ & 0.944 & & $1.08 \%$ & 0.4434 & & $0.46 \%$ & 0.3732 \\
\hline & $(-5,+5)$ & CAAR $=0$ & & $0.56 \%$ & 0.7952 & & $0.82 \%$ & 0.577 & & $0.33 \%$ & 0.9058 & & $2.82 \%$ & $0.0134^{*}$ \\
\hline & $(-10,+10)$ & CAAR $=0$ & & $-3.70 \%$ & 0.237 & & $-0.94 \%$ & 0.6796 & & $-0.20 \%$ & & & $1.64 \%$ & 0.3612 \\
\hline 7 & $(-2,+2)$ & CAAR $=0$ & 72 & $1.76 \%$ & $0.0777 \$$ & 40 & $1.21 \%$ & $0.0835 \$$ & 25 & $2.47 \%$ & 0.3782 & 186 & $1.77 \%$ & $0.0013^{\star *}$ \\
\hline & $(-1,+1)$ & CAAR $=0$ & & $0.87 \%$ & 0.25 & & $0.64 \%$ & 0.2305 & & $2.28 \%$ & 0.2386 & & $0.99 \%$ & $0.0154^{*}$ \\
\hline & $(-5,+5)$ & CAAR $=0$ & & $-1.22 \%$ & 0.4357 & & $-0.73 \%$ & 0.4966 & & $4.46 \%$ & 0.4107 & & $-0.35 \%$ & 0.6907 \\
\hline & $(-10,+10)$ & CAAR $=0$ & & $2.20 \%$ & 0.3334 & & $1.40 \%$ & 0.3677 & & $11.28 \%$ & 0.2225 & & $2.70 \%$ & $0.045^{\star}$ \\
\hline 8 & $(-6,+1)$ & CAAR $=0$ & 72 & $0.68 \%$ & 0.5844 & 40 & $0.70 \%$ & 0.4397 & 25 & $0.77 \%$ & 0.7819 & 187 & $1.05 \%$ & 0.208 \\
\hline & $(-1,+1)$ & CAAR $=0$ & & $0.86 \%$ & 0.2439 & & $-0.89 \%$ & 0.1057 & & $0.93 \%$ & 0.5383 & & $0.81 \%$ & $0.0644 \$$ \\
\hline & $(-5,+5)$ & CAAR $=0$ & & $-1.38 \%$ & 0.3551 & & $1.59 \%$ & 0.144 & & $1.29 \%$ & 0.7128 & & $0.04 \%$ & 0.9633 \\
\hline & $(-10,+10)$ & CAAR $=0$ & & $-1.34 \%$ & 0.5453 & & $0.27 \%$ & 0.8648 & & $1.51 \%$ & 0.7956 & & $0.15 \%$ & 0.9285 \\
\hline 9 & $(-1,+1)$ & CAAR $=0$ & 72 & $-1.02 \%$ & 0.168 & 39 & $-0.07 \%$ & 0.91 & 25 & $-3.32 \%$ & $0.0086^{* *}$ & 183 & $-0.53 \%$ & 0.2149 \\
\hline & $(-5,+5)$ & CAAR $=0$ & & $-1.06 \%$ & 0.4704 & & $1.25 \%$ & 0.3055 & & $0.65 \%$ & 0.7986 & & 1.2 & 0.1452 \\
\hline & $(-10,+10)$ & CAAR $=0$ & & $1.33 \%$ & 0.5214 & & $6.86 \%$ & $01^{* * *}$ & & & 583 & & & $003^{* \star *}$ \\
\hline 10 & $(-1,+1)$ & CAAR $=0$ & 72 & $1.69 \%$ & $0.0246^{*}$ & 39 & $1.17 \%$ & $0.0617 \$$ & 25 & $2.07 \%$ & 0.103 & 183 & $1.61 \%$ & $0.0002^{* * *}$ \\
\hline & $(-5,+5)$ & CAAR $=0$ & & $0.57 \%$ & 0.6922 & & $3.12 \%$ & $0.0105^{*}$ & & & & & & $0.0114^{*}$ \\
\hline & $(-10,+10)$ & CAAR $=0$ & & $-0.16 \%$ & 0.9377 & & $7.63 \%$ & $0.0001^{* * *}$ & & & & & & $0.0136^{*}$ \\
\hline 11 & $(-1,+1)$ & CAAR $=0$ & 72 & $\mid-0.59 \%$ & 0.4197 & 39 & $1.15 \%$ & $0.0726 \$$ & 25 & $-1.51 \%$ & 0.2349 & 183 & $-0.51 \%$ & 0.234 \\
\hline & $(-5,+5)$ & \begin{tabular}{|l|} 
CAAR $=0$ \\
\end{tabular} & & $-2.68 \%$ & $0.0739 \$$ & & $1.89 \%$ & 0.1408 & & & & & & $0.0024^{* *}$ \\
\hline & $(-10,+10)$ & CAAR $=0$ & & $-4.81 \%$ & $0.0207^{*}$ & & $-3.45 \%$ & $0.0527 \$$ & & -3 & 37 & & $-6.15 \%$ & $0.0001^{* * *}$ \\
\hline 12 & $(-4,0)$ & CAAR $=0$ & 71 & $-0.54 \%$ & 0.5734 & 39 & $-1.07 \%$ & 0.2146 & 25 & $-1.68 \%$ & 0.3134 & 182 & $-1.25 \%$ & $0.0273^{*}$ \\
\hline & $(-1,+1)$ & CAAR=0 & & $-1.35 \%$ & $0.0725 \$$ & & $-1.88 \%$ & $0.0048^{* *}$ & & -2.5 & $0.0458^{*}$ & & & $0.0001^{* * *}$ \\
\hline & $(-5,+5)$ & CAAR $=0$ & & $-2.95 \%$ & $0.047^{*}$ & & $-4.68 \%$ & $0.0004^{* * *}$ & & $-5.35 \%$ & $0.0382^{*}$ & & $-5.03 \%$ & $0.0001^{* * *}$ \\
\hline & $(-10,+10)$ & CAAR $=0$ & & $-5.59 \%$ & $0.0074^{* *}$ & & $-8.89 \%$ & $0.0001^{* * *}$ & & $-6.85 \%$ & $0.0617 \$$ & & $-7.21 \%$ & $0.0001^{* * *}$ \\
\hline 13 & $(-1,+1)$ & CAAR=0 & 71 & $-0.99 \%$ & 0.1853 & 39 & $-1.73 \%$ & $0.0097^{* \star}$ & 25 & $-0.68 \%$ & 0.5906 & 182 & $-1.81 \%$ & $0.0001^{* * *}$ \\
\hline & $(-5,+5)$ & CAAR $=0$ & & $-0.75 \%$ & 0.6075 & & $-5.02 \%$ & $0.0001^{* * *}$ & & $-3.95 \%$ & 0.12 & & $-3.29 \%$ & $0.0002^{* * *}$ \\
\hline & $(-10,+10)$ & CAAR $=0$ & & $-2.22 \%$ & 0.2855 & & $-3.43 \%$ & $0.0627 \$$ & & $-4.26 \%$ & 0.2421 & & $-3.10 \%$ & $0.0131^{*}$ \\
\hline
\end{tabular}

***Significant at $0.1 \%$ level; **Significant at $1 \%$ level;

${ }^{*}$ Significant at $5 \%$ level; \$Significant at $10 \%$ level. 
Table 3: Results of the Multivariate Regression Model Analysis

\begin{tabular}{|c|c|c|c|c|c|c|c|c|c|c|c|c|c|c|c|c|c|}
\hline \multirow[b]{2}{*}{ No. } & \multirow[b]{2}{*}{ Windows } & \multirow[b]{2}{*}{ Hypotheses } & \multicolumn{3}{|c|}{ REIT } & \multicolumn{3}{|c|}{ Construction } & \multicolumn{3}{|c|}{ Transportation } & \multicolumn{3}{|c|}{ Utility } & \multicolumn{3}{|c|}{ Bank (MktCap >= 200M) } \\
\hline & & & $\overline{\mathbf{N}}$ & CAAR & Prob>F & $\mathbf{N}$ & CAAR & Prob>F & $\mathbf{N}$ & CAAR & Prob>F & $\mathbf{N}$ & CAAR & Prob $>F$ & $\mathbf{N}$ & CAAR & Prob $>F$ \\
\hline \multirow[t]{5}{*}{1} & $(-2,+2)$ & CAAR $=0$ & \multirow[t]{5}{*}{189} & $-0.55 \%$ & 0.1577 & \multirow[t]{5}{*}{28} & $-0.15 \%$ & 0.9519 & \multirow[t]{5}{*}{121} & $0.15 \%$ & 0.8593 & \multirow[t]{5}{*}{60} & $-1.08 \%$ & 0.298 & \multirow[t]{5}{*}{191} & $-5.21 \%$ & $0.0001^{* * *}$ \\
\hline & $(-5,+1)$ & CAAR $=0$ & & $-1.66 \%$ & $0.0005^{\star \star \star}$ & & $2.18 \%$ & 0.4825 & & $1.80 \%$ & $0.095 \$$ & & $1.31 \%$ & 0.354 & & $-8.36 \%$ & $0.0001^{* \star *}$ \\
\hline & $(-1,+1)$ & CAAR $=0$ & & $-0.34 \%$ & 0.2567 & & $-1.46 \%$ & 0.4663 & & $2.86 \%$ & $0.0001^{* * *}$ & & $-0.84 \%$ & 0.253 & & $-1.84 \%$ & $0.0001^{* * *}$ \\
\hline & $(-5,+5)$ & CAAR $=0$ & & $-2.12 \%$ & $0.0005^{* * *}$ & & $1.88 \%$ & 0.6307 & & $-0.52 \%$ & 0.7021 & & $3.05 \%$ & 0.134 & & $-10.54 \%$ & $0.0001^{* * *}$ \\
\hline & $(-10,+10)$ & CAAR $=0$ & & $-3.62 \%$ & $0.0001^{* * *}$ & & $4.69 \%$ & 0.3975 & & $2.22 \%$ & 0.259 & & $3.77 \%$ & 0.2903 & & $-9.02 \%$ & $0.0001^{* * *}$ \\
\hline \multirow[t]{4}{*}{2} & $(0,+1)$ & CAAR $=0$ & \multirow[t]{4}{*}{189} & $-0.84 \%$ & $0.0007^{\star \star \star}$ & 28 & $0.90 \%$ & 0.5819 & 121 & $0.90 \%$ & 0.1089 & 60 & $1.10 \%$ & 0.1035 & 191 & $-0.02 \%$ & 0.9002 \\
\hline & $(-1,+1)$ & CAAR $=0$ & & $-0.98 \%$ & $0.0012^{\star *}$ & & $-0.31 \%$ & 0.8759 & & $-2.03 \%$ & $0.0001^{* \star *}$ & & $0.82 \%$ & 0.343 & & $-1.47 \%$ & $0.0001^{* * *}$ \\
\hline & $(-5,+5)$ & CAAR $=0$ & & $-3.26 \%$ & $0.0001^{* * *}$ & & $0.33 \%$ & 0.9312 & & $-1.41 \%$ & 0.3062 & & $-3.53 \%$ & 0.117 & & $-6.53 \%$ & $0.0001^{* * *}$ \\
\hline & $(-10,+10)$ & CAAR $=0$ & & $-6.74 \%$ & $0.0001^{* * *}$ & & $4.22 \%$ & 0.4491 & & $1.33 \%$ & 0.5055 & & $-3.92 \%$ & 0.3127 & & $-14.10 \%$ & $0.0001^{* * *}$ \\
\hline 3 & $(-1,+1)$ & CAAR $=0$ & 187 & $-0.06 \%$ & 0.8548 & 25 & $\mid-0.49 \%$ & 0.7692 & 123 & $-0.06 \%$ & 0.9493 & \begin{tabular}{|l|}
59 \\
\end{tabular} & $-0.14 \%$ & 0.8145 & 190 & $-0.97 \%$ & $0.001^{* * *}$ \\
\hline & $(-5,+5)$ & CAAR $=0$ & & $-1.25 \%$ & $0.0801 \$$ & & $1.97 \%$ & 0.5494 & & $4.60 \%$ & $0.0633 \$$ & & $2.55 \%$ & $0.059 \$$ & & $-0.74 \%$ & 0.22 \\
\hline & $(-10,+10)$ & CAAR $=0$ & & $-4.65 \%$ & $0.0001^{\star * *}$ & & $0.54 \%$ & 0.9071 & & $10.06 \%$ & $0.0157^{*}$ & & $-2.71 \%$ & 0.2057 & & $-1.16 \%$ & 0.1992 \\
\hline 4 & $(-1,+1)$ & CAAR $=0$ & 187 & $-0.57 \%$ & 0.1112 & 24 & $0.97 \%$ & 0.5573 & 123 & $1.53 \%$ & 0.1028 & 59 & $1.19 \%$ & $0.0443^{*}$ & 190 & $-0.75 \%$ & $0.0123^{*}$ \\
\hline & $(-5,+5)$ & CAAR $=0$ & & $-1.39 \%$ & $0.0527 \$$ & & $0.59 \%$ & 0.8 & & $4.25 \%$ & $84^{*}$ & & $2.27 \%$ & $0.0792 \$$ & & $3 \%$ & 54 \\
\hline & $(-10,+10)$ & CAAR $=0$ & & $-1.56 \%$ & 0.13 & & $-0.26 \%$ & 0.9533 & & $7.02 \%$ & $0.0444^{*}$ & & $3.40 \%$ & $0.0921 \$$ & & $-1.87 \%$ & $407^{*}$ \\
\hline 5 & $(-1,+2)$ & CAAR $=0$ & 185 & $-0.43 \%$ & 0.296 & 24 & $\mid-0.97 \%$ & 0.6152 & 120 & $1.66 \%$ & $0.0995 \$$ & 59 & $-1.50 \%$ & $0.0164^{*}$ & 190 & $-0.63 \%$ & $652 \$$ \\
\hline & $(-1,+1)$ & CAAR $=0$ & & $-0.14 \%$ & 0.6825 & & $0.82 \%$ & 0.6 & & $0.94 \%$ & & & $-1.42 \%$ & $0.0078^{* *}$ & & -0 & \\
\hline & $(-5,+5)$ & CAA & & $-1.38 \%$ & $0.0521 \$$ & & $-0.97 \%$ & 0.7 & & $0.35 \%$ & 0.8 & & $-3.71 \%$ & $0.0009^{* * *}$ & & $\%$ & 838 \\
\hline & $(-10,+10)$ & CAAR $=0$ & & $-1.64 \%$ & 0.1 & & $1.05 \%$ & $0 . \varepsilon$ & & $7.56 \%$ & $65^{\star *}$ & & $-6.57 \%$ & $0.0001^{* * *}$ & & $3 \%$ & $0.0078^{* *}$ \\
\hline 6 & $(0,+1)$ & CAAR $=0$ & 186 & $1.13 \%$ & $0.0001^{* * *}$ & 24 & $1.22 \%$ & 0.3704 & 120 & $-0.08 \%$ & 99 & 60 & $0.12 \%$ & 0.7225 & 189 & $5 \%$ & $052^{* *}$ \\
\hline & $(-1,+1)$ & CAAR $=0$ & & $1.08 \%$ & $0.0037^{* *}$ & & $1.01 \%$ & 0.5 & & $0.54 \%$ & 94 & & $2.24 \%$ & $01^{* * *}$ & & $\%$ & $21^{\text {** }}$ \\
\hline & $(-5,+5)$ & CAAR $=0$ & & $3.89 \%$ & $0.0001^{* * *}$ & & 4.7 & 0.1 & & $-1.13 \%$ & 19 & & $6.69 \%$ & $0.0001^{* * *}$ & & $3 \%$ & $588 \$$ \\
\hline & $(-10$ & $\overline{C A}$ & & $5.14 \%$ & $7^{\star \star \star *}$ & & 13 & $8^{\star *}$ & & $1.87 \%$ & 71 & & $4.42 \%$ & $79^{* *}$ & & $2 \%$ & $38^{\star *}$ \\
\hline 7 & $(-2,+2)$ & CA & 181 & $-0.24 \%$ & 0.5474 & 23 & $2.05 \%$ & 0.4004 & 111 & $2.80 \%$ & $0.0013^{* *}$ & 57 & $-1.15 \%$ & $0.0467^{*}$ & 186 & $0.76 \%$ & $0.0207^{\star}$ \\
\hline & $(-1,+1)$ & CAA & & $-0.18 \%$ & 0.5 & & $3.37 \%$ & 0.0 & & $2.07 \%$ & $0.0018^{* *}$ & & $-0.30 \%$ & 0.4 & & $\%$ & 932 \\
\hline & $(-5,+5)$ & CAAR $=0$ & & $0.52 \%$ & 0.3 & & $3.25 \%$ & 0. & & $3.35 \%$ & 0.0 & & $-2.14 \%$ & $0.0165^{*}$ & & $3 \%$ & $24^{*}$ \\
\hline & $(-10,+10)$ & CAAR=0 & & $3.92 \%$ & $1^{* * *}$ & & $5.29 \%$ & 0. & & $5.70 \%$ & $25^{\star *}$ & & $-2.66 \%$ & $0.0363^{*}$ & & $2.49 \%$ & $004^{\star \star \star}$ \\
\hline 8 & $(-6,+1)$ & CAAR $=0$ & 180 & $0.83 \%$ & 0.1037 & 23 & $0.23 \%$ & 0.9415 & 110 & $0.80 \%$ & 0.4557 & 57 & $0.00 \%$ & 0.9986 & 186 & $1.88 \%$ & $0.0001^{* * *}$ \\
\hline & $(-1,+1)$ & CAAR $=0$ & & $0.24 \%$ & 0.4265 & & $-0.23 \%$ & 0.9046 & & $1.60 \%$ & $0.0136^{*}$ & & $-0.61 \%$ & 0.1683 & & $6 \%$ & 0.1523 \\
\hline & $(-5,+5)$ & CAAR $=0$ & & $2.51 \%$ & $0.0001^{* * *}$ & & $0.40 \%$ & 0.9149 & & $-0.02 \%$ & 0.9846 & & $-0.29 \%$ & 0.7345 & & $3.65 \%$ & $0.0001^{* * *}$ \\
\hline & $(-10,+10)$ & CAAR $=0$ & & $-0.31 \%$ & 0.7251 & & $-3.21 \%$ & 0.5502 & & $2.72 \%$ & 0.1404 & & $-1.50 \%$ & 0.2386 & & $5.09 \%$ & $0.0001^{* \star *}$ \\
\hline 9 & $(-1,+1)$ & CAAR $=0$ & 178 & $-0.78 \%$ & $0.0252^{*}$ & 21 & $4.54 \%$ & $0.0296^{*}$ & 103 & $1.58 \%$ & $0.0142^{*}$ & 57 & $0.80 \%$ & 0.1783 & 184 & $-1.97 \%$ & $0.0001^{* * *}$ \\
\hline & $(-5,+5)$ & CAAR $=0$ & & $-6.03 \%$ & $0.0001^{* * *}$ & & $0.74 \%$ & 0.8548 & & $0.68 \%$ & 0. & & $-4.33 \%$ & $0.0003^{* * *}$ & & $-1.34 \%$ & $116^{*}$ \\
\hline & $(-10,+10)$ & CAAR $=0$ & & $-4.80 \%$ & $0.0001^{* \star *}$ & & $7.99 \%$ & 0. & & $0.91 \%$ & 083 & & $-5.79 \%$ & $0.0005^{\star * *}$ & & $1.52 \%$ & $401^{*}$ \\
\hline 10 & $(-1,+1)$ & CAAR $=0$ & 178 & $-2.70 \%$ & $0.0001^{* * *}$ & 21 & $-0.46 \%$ & 0.8233 & 103 & $0.14 \%$ & 0.8197 & \begin{tabular}{|l|}
57 \\
\end{tabular} & $-2.96 \%$ & $0.0001^{\star * *}$ & 184 & $0.64 \%$ & $0.0181^{*}$ \\
\hline & $(-5,+5)$ & CAAR $=0$ & & $-5.34 \%$ & $0.0001^{* \star *}$ & & $6.03 \%$ & 0.1299 & & $-0.35 \%$ & 0.7811 & & $-4.40 \%$ & $0.0002^{\star * *}$ & & $4 \%$ & $0.0304^{*}$ \\
\hline & $(-10,+10)$ & CAAR $=0$ & & $-7.21 \%$ & $0.0001^{* * *}$ & & $9.63 \%$ & $0.0851 \$$ & & $2.76 \%$ & 0.1194 & & $-2.74 \%$ & 0.1027 & & $1.44 \%$ & $0.0509 \$$ \\
\hline 11 & $(-1,+1)$ & CAAR $=0$ & 177 & $\mid-0.79 \%$ & $0.0235^{*}$ & 21 & $\mid-0.42 \%$ & 0.8437 & 103 & $-0.44 \%$ & 0.4913 & 57 & $-0.44 \%$ & 0.4847 & 184 & $-1.07 \%$ & $0.0001^{\star \star \star}$ \\
\hline & $(-5,+5)$ & CAAR $=0$ & & $-2.59 \%$ & $0.0002^{* * *}$ & & $5.83 \%$ & 0. & & $0.59 \%$ & 64 & & $2.21 \%$ & $0.0815 \$$ & & $2 \%$ & 487 \\
\hline & $(-10,+1$ & CAAR $=0$ & & $-7.65 \%$ & $0.0001^{* * *}$ & & $7.03 \%$ & 0.2301 & & $-2.71 \%$ & 0.1289 & & $-2.01 \%$ & 0.2513 & & $-3.66 \%$ & $0.0001^{* * *}$ \\
\hline 12 & $(-4,0)$ & CAAR $=0$ & 176 & $-1.50 \%$ & $0.0011^{* *}$ & 21 & $\mid-0.69 \%$ & 0.8214 & 102 & $-5.06 \%$ & $0.0001^{* * *}$ & \begin{tabular}{|l|l}
57 \\
\end{tabular} & $2.39 \%$ & $0.0056^{* *}$ & 183 & $-0.44 \%$ & 0.2237 \\
\hline & $(-1,+1)$ & CAAR $=0$ & & $-1.29 \%$ & $0.0003^{* * *}$ & & $0.51 \%$ & 0.8274 & & $-1.65 \%$ & $0.0132^{*}$ & & $0.41 \%$ & 0.5357 & & $0.44 \%$ & 0.1147 \\
\hline & $(-5,+5)$ & CAAR $=0$ & & $-3.69 \%$ & $0.0001^{* * *}$ & & $-2.00 \%$ & 0.6654 & & $-7.08 \%$ & $0.0001^{* \star *}$ & & $1.45 \%$ & 0.2653 & & $-2.64 \%$ & $0.0001^{* * *}$ \\
\hline & $(-10,+10)$ & CAAR $=0$ & & $-3.53 \%$ & $0.0003^{* * *}$ & & $3.25 \%$ & 0.6164 & & $-6.93 \%$ & $0.0001^{* * *}$ & & $-4.96 \%$ & $0.0067^{* *}$ & & $-8.00 \%$ & $0.0001^{* * *}$ \\
\hline 13 & $(-1,+1)$ & CAAR $=0$ & 176 & $-0.77 \%$ & $0.0273^{*}$ & 21 & $-1.07 \%$ & 0.6584 & 102 & $-1.70 \%$ & $0.011^{*}$ & 57 & $-1.90 \%$ & $0.0045^{\star *}$ & 183 & $-1.46 \%$ & $0.0001^{* * *}$ \\
\hline & $(-5,+5)$ & CAAR $=0$ & & $-1.92 \%$ & $0.0053^{\star *}$ & & $5.55 \%$ & 0.239 & & $-4.72 \%$ & $0.0003^{* \star *}$ & & $-2.32 \%$ & $0.0746 \$$ & & $-3.25 \%$ & $0.0001^{* * *}$ \\
\hline & $(-10,+10)$ & CAAR $=0$ & & $-2.57 \%$ & $0.0078^{* *}$ & & $4.35 \%$ & 0.5118 & & $-5.90 \%$ & $0.0013^{* *}$ & & $0.80 \%$ & 0.6605 & & $-2.98 \%$ & $0.0001^{* * *}$ \\
\hline
\end{tabular}

***Significant at $0.1 \%$ level; **Significant at $1 \%$ level;

${ }^{*}$ Significant at $5 \%$ level; \$Significant at $10 \%$ level. 
Figure 1: Coverage under the TRIA of 2002

\begin{tabular}{|c|c|}
\hline $\begin{array}{l}\text { Overall Liability Limit }=\$ 100 \text { Billion } \\
\text { Federal Share: } \\
90 \% \text { with Discretionary Recoupment }\end{array}$ & 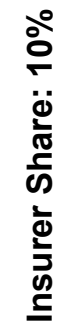 \\
\hline $\begin{array}{l}\text { Deductible and Mandatory Recoupmen } \\
\text { Deductible (\% of Premiums): } 7 \% 2003, \\
\text { Aggregate Retention Limit: } \$ 10 \mathrm{~B} 2003 \text {, }\end{array}$ & \\
\hline
\end{tabular}

Figure 2: Stock Price Impact of the Passage of TRIA (11/20/2002)

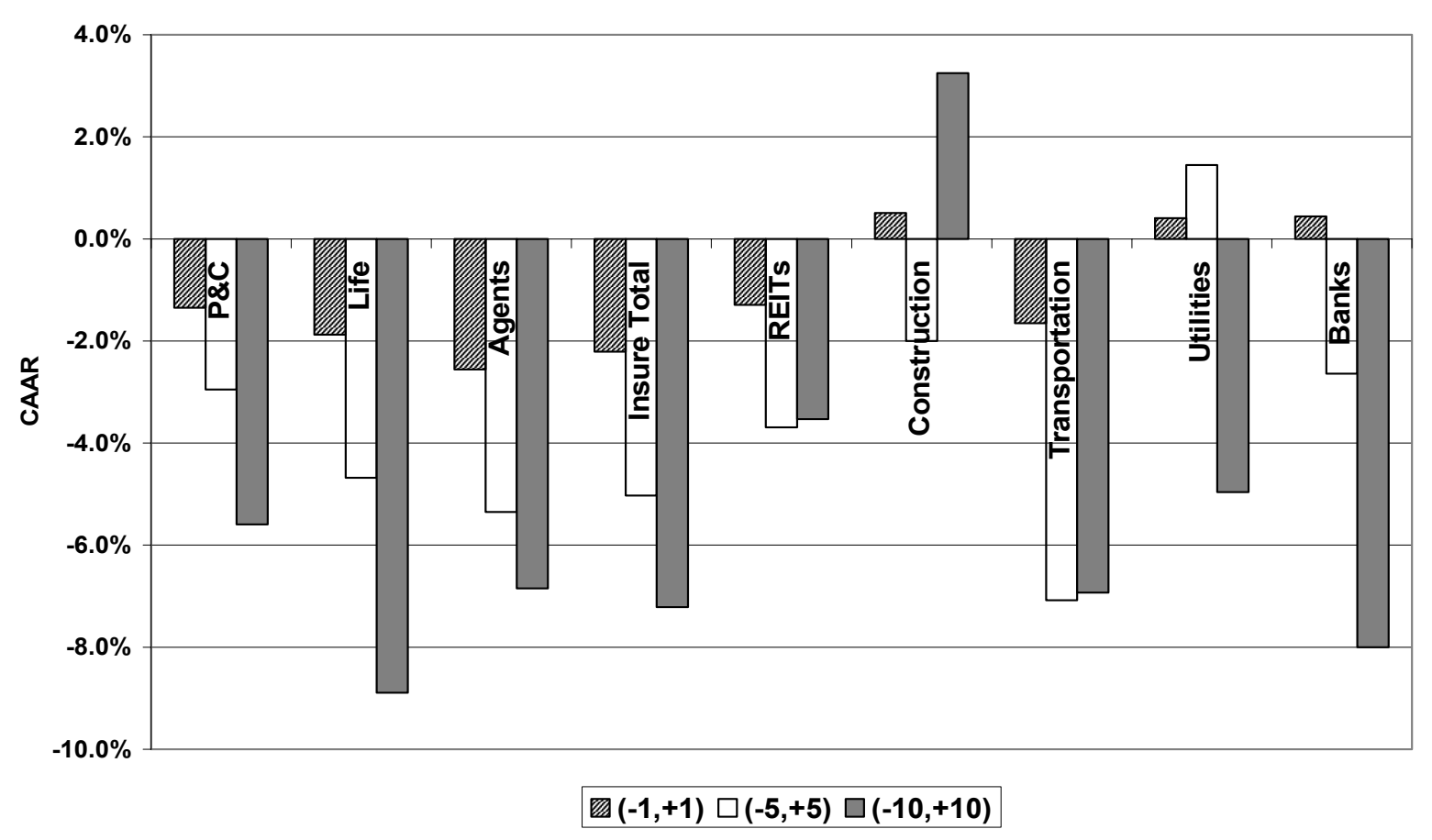


Figure 3: P\&C Insurers Average CAAR -- All TRIA Events

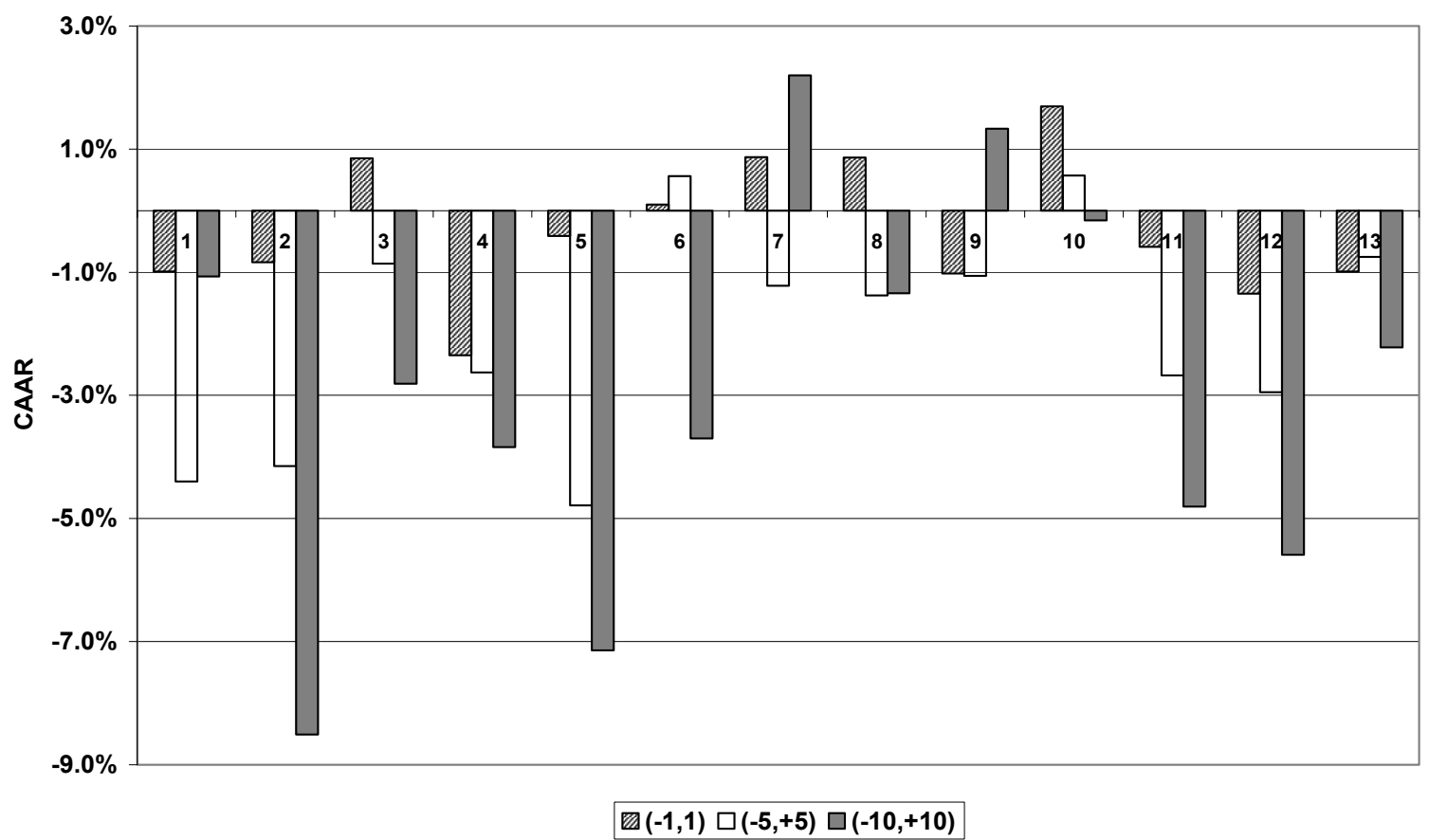

Figure 4: Commercial P\&C Premium Rate Change By Line

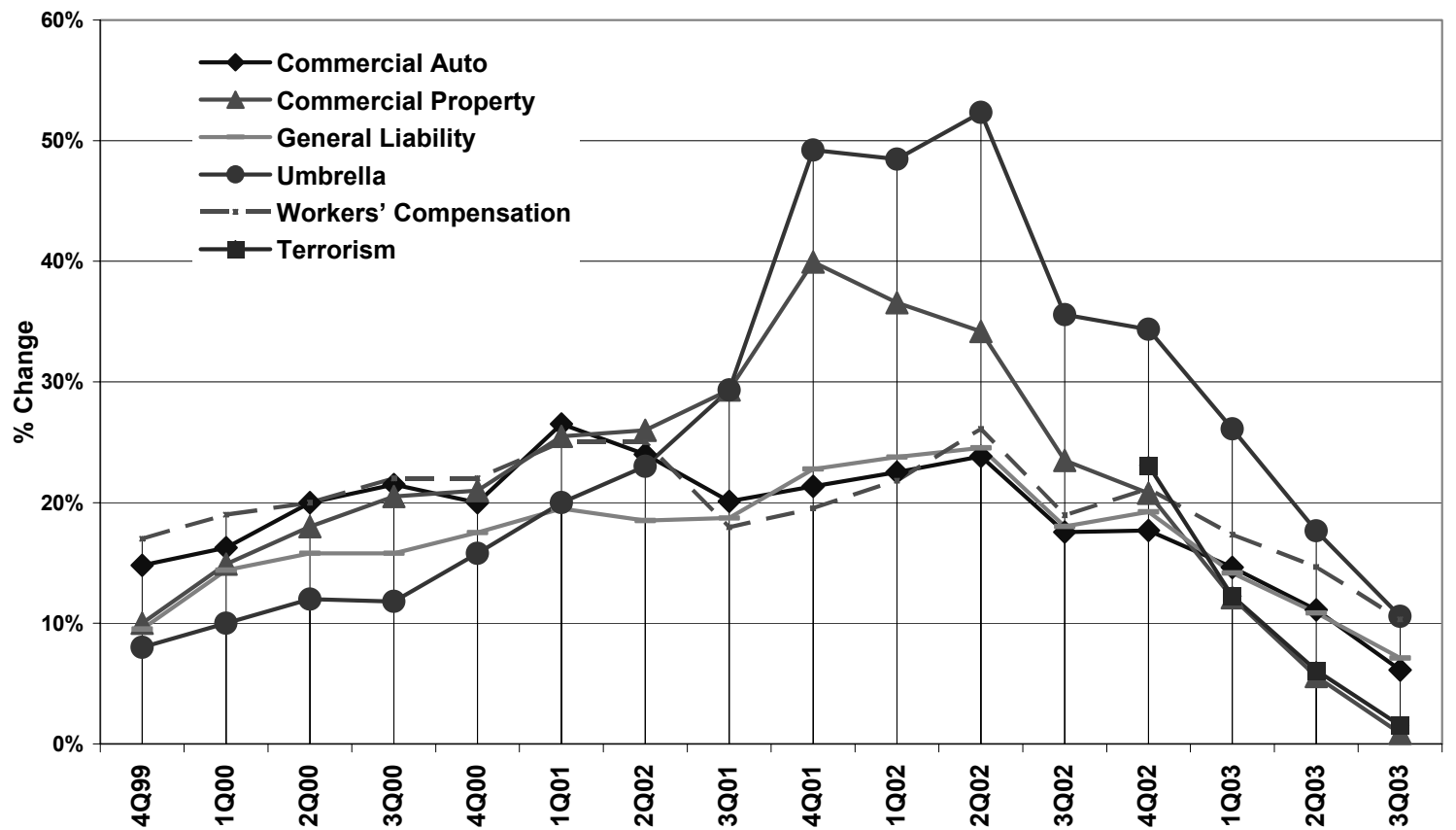

Source: Council of Insurance Agents and Brokers. 
Figure 5: Value of New Construction Put In Place

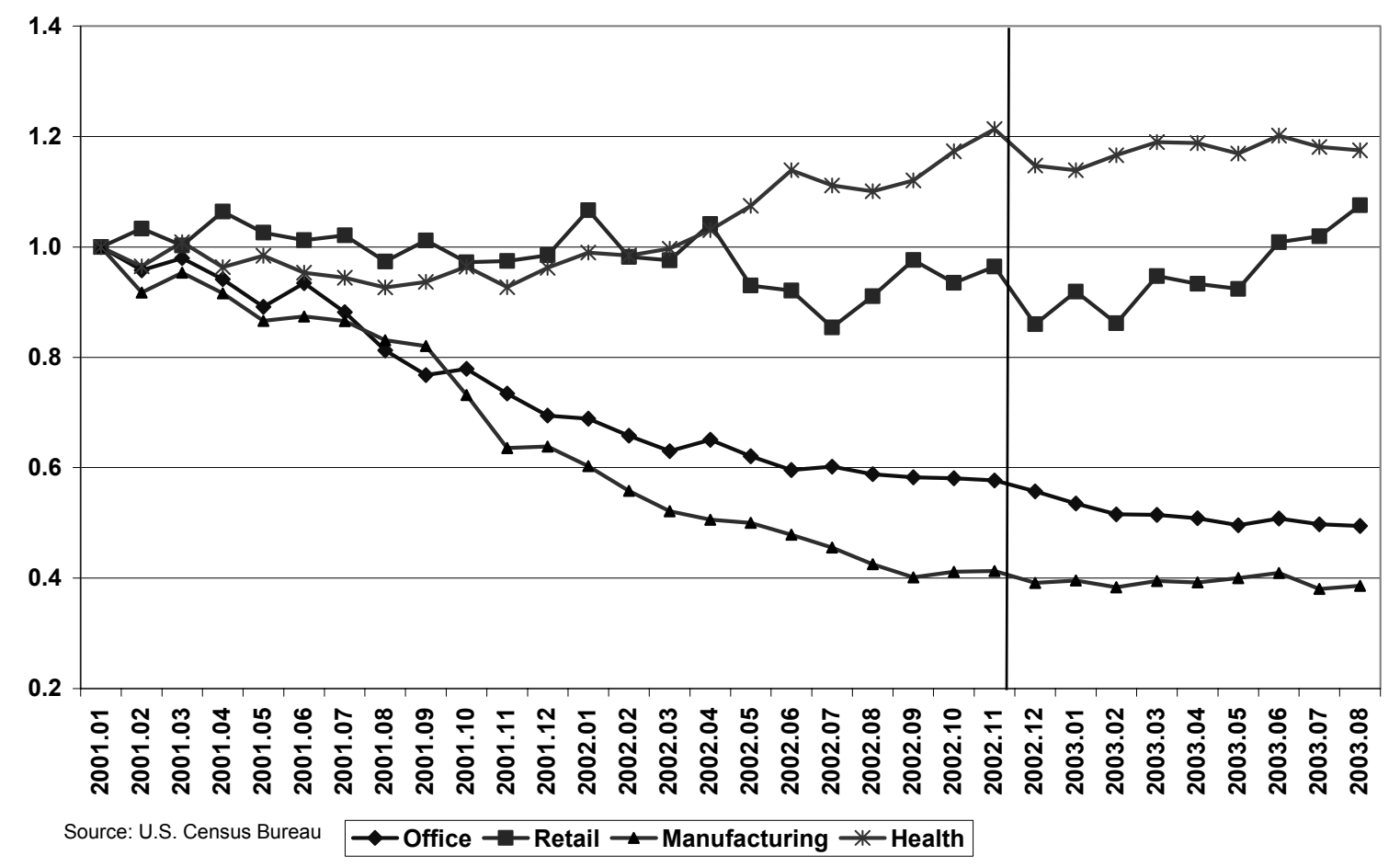

Figure 6: Total Non-Farm Private Sector Construction Employment (SA)

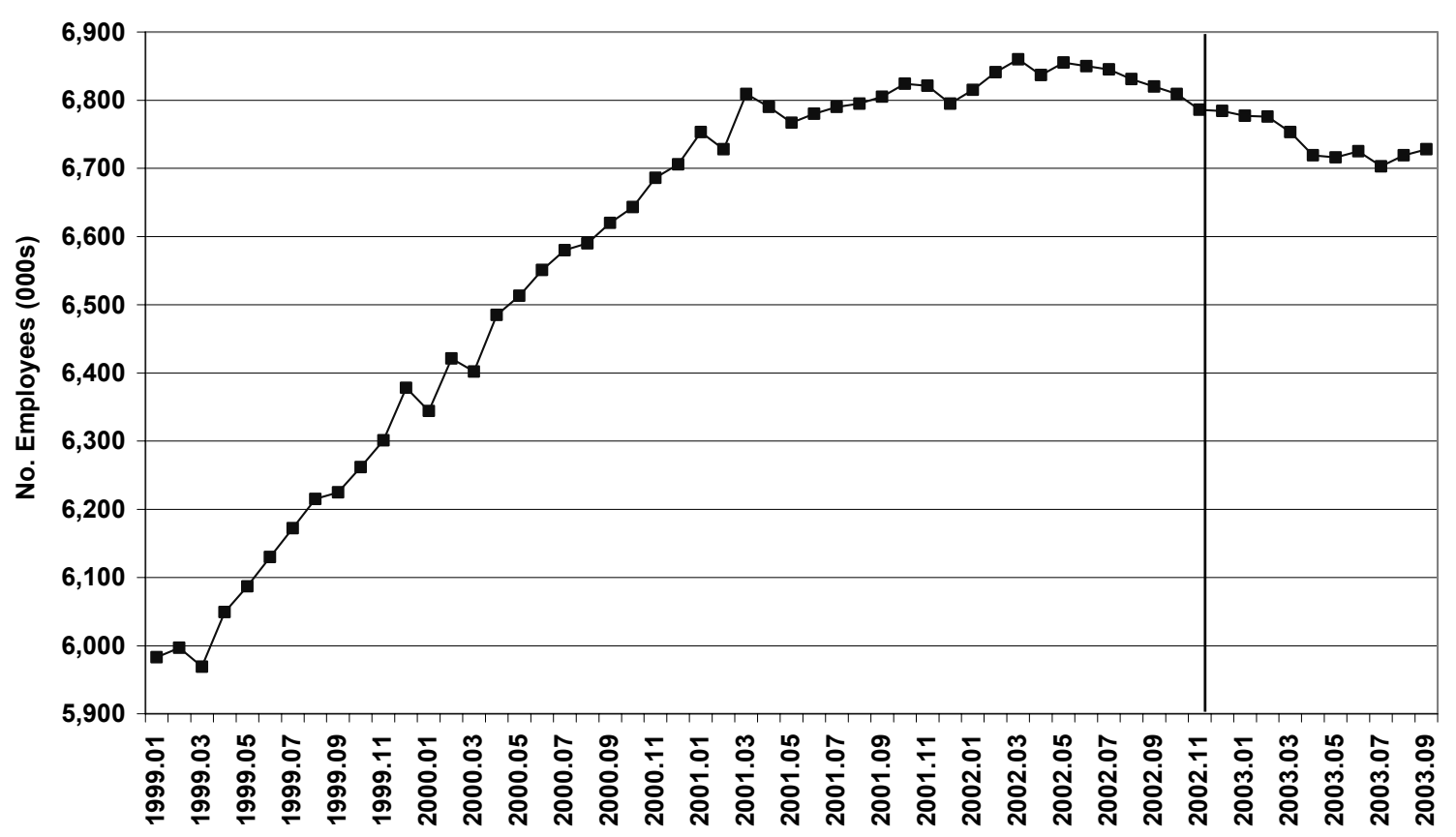

Source: U.S. Bureau of Labor Statistics, non-farm private sector construction employment. 